\title{
Fate of nitrogen in agriculture and environment: agronomic, eco-physiological and molecular approaches to improve nitrogen use efficiency
}

\author{
Muhammad Anas ${ }^{1,2}$, Fen Liao ${ }^{2}$, Krishan K. Verma², Muhammad Aqeel Sarwar ${ }^{3}$, Aamir Mahmood', \\ Zhong-Liang Chen ${ }^{2}$, Qiang Li ${ }^{1}$, Xu-Peng Zeng ${ }^{1}$, Yang Liu ${ }^{4^{*}}$ and Yang-Rui Li $i^{1,2^{*}}$
}

\begin{abstract}
Nitrogen is the main limiting nutrient after carbon, hydrogen and oxygen for photosynthetic process, phyto-hormonal, proteomic changes and growth-development of plants to complete its lifecycle. Excessive and inefficient use of $\mathrm{N}$ fertilizer results in enhanced crop production costs and atmospheric pollution. Atmospheric nitrogen (71\%) in the molecular form is not available for the plants. For world's sustainable food production and atmospheric benefits, there is an urgent need to up-grade nitrogen use efficiency in agricultural farming system. The nitrogen use efficiency is the product of nitrogen uptake efficiency and nitrogen utilization efficiency, it varies from 30.2 to $53.2 \%$. Nitrogen losses are too high, due to excess amount, low plant population, poor application methods etc., which can go up to $70 \%$ of total available nitrogen. These losses can be minimized up to 15-30\% by adopting improved agronomic approaches such as optimal dosage of nitrogen, application of $\mathrm{N}$ by using canopy sensors, maintaining plant population, drip fertigation and legume based intercropping. A few transgenic studies have shown improvement in nitrogen uptake and even increase in biomass. Nitrate reductase, nitrite reductase, glutamine synthetase, glutamine oxoglutarate aminotransferase and asparagine synthetase enzyme have a great role in nitrogen metabolism. However, further studies on carbon-nitrogen metabolism and molecular changes at omic levels are required by using "whole genome sequencing technology" to improve nitrogen use efficiency. This review focus on nitrogen use efficiency that is the major concern of modern days to save economic resources without sacrificing farm yield as well as safety of global environment, i.e. greenhouse gas emissions, ammonium volatilization and nitrate leaching.
\end{abstract}

Keywords: Nitrogen use efficiency, Assimilation, Nitrate, Ammonium, Enzyme, Fertilizer

*Correspondence: yangliutibs@126.com; liyr@gxaas.net

2 Key Laboratory of Sugarcane Biotechnology and Genetic Improvement (Guangxi), Ministry of Agriculture/Guangxi Key Laboratory of Sugarcane Genetic Improvement, Sugarcane Research Institute, Guangxi Academy of Agricultural Sciences, Nanning 530007, Guangxi, China

${ }^{4}$ Guangxi Crop Genetic Improvement and Biotechnology Laboratory, Nanning 530007, China

Full list of author information is available at the end of the article

\section{Introduction}

Nitrogen $(\mathrm{N})$ plays an important role in crop plants. It is involved in various critical processes, such as growth, leaf area-expansion and biomass-yield production. Excess NUE can support good plant performance and better crop out-put. Various plant molecules such as amino acids, chlorophyll, nucleic acids, ATP and phyto-hormones, that contains nitrogen as a structural part, are necessary to complete the biological processes, involving carbon and nitrogen metabolisms, photosynthesis and

c) The Author(s) 2020. This article is licensed under a Creative Commons Attribution 4.0 International License, which permits use, sharing, adaptation, distribution and reproduction in any medium or format, as long as you give appropriate credit to the original author(s) and the source, provide a link to the Creative Commons licence, and indicate if changes were made. The images or other third party material in this article are included in the article's Creative Commons licence, unless indicated otherwise in a credit line to the material. If material is not included in the article's Creative Commons licence and your intended use is not permitted by statutory regulation or exceeds the permitted use, you will need to obtain permission directly from the copyright holder. To view a copy of this licence, visit http://creativeco mmons.org/licenses/by/4.0/. The Creative Commons Public Domain Dedication waiver (http://creativecommons.org/publicdomain/ zero/1.0/) applies to the data made available in this article, unless otherwise stated in a credit line to the data. 
protein production [1,2]. Insufficient amount of $\mathrm{N}$ available to plants can hinder the growth and development. Nitrogen can also improve root growth, increase the volume, area, diameter, total and main root length, dry mass and subsequently increase nutrient uptake and enhance nutrient balance and dry mass production [3-6].

Application of nitrogen increases greenness of plants, $\mathrm{CO}_{2}$ assimilation rate, crop quality-yield and improve resistance to environmental stresses such as limited water availability and saline soil conditions [7, 8]. Hou et al. [9] found that nitrogen application more important than the other major essential fertilizers/nutrient for successful crop production. Consequently, $\mathrm{N}$ requirement is the most central feature for plant production [10]. Slow development of plant and early leaf senescence due to deficient $\mathrm{N}$ can cause decreased both crop production and quality [11]. Excessive $\mathrm{N}$ fertilizer application is common practice by farmers of cotton regions in the northwest [12] which is not cost effective for crop production, and excess $\mathrm{N}$ prolongs the vegetative growth period, delays maturity [13], decrease sugar content, and also attracts insect pest and causes disease epidemics.

China has only $7 \%$ of global farm land with $20 \%$ world population that depends on it for feed [14-16]. It boosts up average yield of grain from 1.09 to 6.51 tonnes ha ${ }^{-1}$ in last 7 decades [17]. In China, chemical nitrogen (N) fertilizer input is the major element for the continuous increase of food production to mitigate the problem of food security [18]. Therefore, the low NUE all over the world especially in agriculture sector is not only wastage of resources (Fig. $1 \mathrm{a}, \mathrm{b}$ ) and also problematic for environmental pollution (Fig. 1c, d) and conflicting to sustainable agricultural productivity [19-21]. product. Numerous demarcations for NUE have been suggested over the years, which have showed a few differences in normal ways $[4,25,26]$.

NUE, NUpE and NUtE can be measured by adopting the Eqs. 1, 2 and 3 [4, 24].

$$
\begin{aligned}
& \mathrm{NUpE}=\mathrm{N} \text { contents in plant } / \mathrm{N} \text { supplied } \\
& \mathrm{NUtE}=\text { Yield } / \mathrm{N} \text { contents in plant } \\
& \mathrm{NUE}=\mathrm{NUpE} \times \mathrm{NUtE}
\end{aligned}
$$

Nitrogen recovery and agronomic nitrogen efficiency (NRE) are the other common approaches used to observe NUE. NRE is termed as the percentage of pragmatic nitrogen fertilizer taken up by crop. It is an indicator for a crop to use the $\mathrm{N}$ fertilizer that has been supplied [27]. The yield increment per unit of $\mathrm{N}$ fertilizer given to the crop is denoted as agronomic nitrogen use efficiency (aNUE). It is an important index to measure gain or loss for excess amount of fertilizer [28]. Best aNUE is the surety of highest benefit-cost-ratio, which is a key economic relationship between input and output that relate both by linear curve [29].

The Eqs. 4 and 5 can be used to measure agronomic and recovery efficiencies like aNUE and NRE:

$$
\text { aNUE }=\left(\mathrm{Y}_{\text {fertilized }}-\mathrm{Y}_{\text {not fertilized }}\right) / \mathrm{F}_{\text {applied }}
$$

$Y_{\text {fertilized }}$ and $Y_{\text {not fertilized }}$ are yields $\left(\mathrm{kg} \mathrm{ha}^{-1}\right)$ when quantity of $\mathrm{N}$ fertilizer applied was $\mathrm{F}$ and zero; $\mathrm{F}_{\text {applied }}$ is the total $\mathrm{N}\left(\mathrm{kg} \mathrm{ha}^{-1}\right)$ applied [28].

$$
\mathrm{NRE}=\left(\text { Total } \mathrm{NU}_{\text {fertilized }}-\text { Total } \mathrm{NU}_{\text {not fertilized }}\right) / \mathrm{N} \text { fertilizer dose }
$$

\section{NUE and its status}

NUE is an exploiting issue for discussion and research which depends on the physiological and metabolic changes, such as soil nitrogen uptake, assimilation from roots to other parts (Fig. 2), source-sink tissues interaction for transportation, signaling and regulatory pathways which are responsible for $\mathrm{N}$ status within plant and growth as well [22]. Normally, the ratio of yield and total $\mathrm{N}$ supplied is termed into NUE [23]. Several techniques have been adopted to observe NUE that can be separated into $\mathrm{N}$ uptake efficiency and $\mathrm{N}$ utilization efficiency. $\mathrm{N}$ uptake efficiency (NUpE) describes the nitrogen amount that a plant can take from sources of nitrogen while $\mathrm{N}$ utilization efficiency (NUtE) termed as the plant capability to assimilate plus remobilize $\mathrm{N}$ within the plant $[4,22$, 24]. However, NUE is the resultant of NUpE and NUtE
Total $\mathrm{NU}_{\text {fertilized }}$ and Total $\mathrm{NU}_{\text {not fertilized }}$ showed $\mathrm{N}$ uptake for $\mathrm{F}$ and no fertilizer, respectively [30].

The variation in NUE can be understood by nitrogen doses, application methods and other agronomic factors which help to manage nitrogen has crucial effect for both profitable crop production and environment [31]. According to field demonstrations, Lou et al., [32] measured NRE and aNUE for different nitrogen rates, application methods and plant population in northwest, China, and found that the $70 \%$ and $80 \%$ of nitrogen loss can be minimized when nitrogen applied through drip fertigation and high plant population, respectively. Drip fertigation and high plant density can increase nitrogen recover efficiency for comparable yield. In contrast conventional method of nitrogen application and low plant population, more nitrogen losses, which 


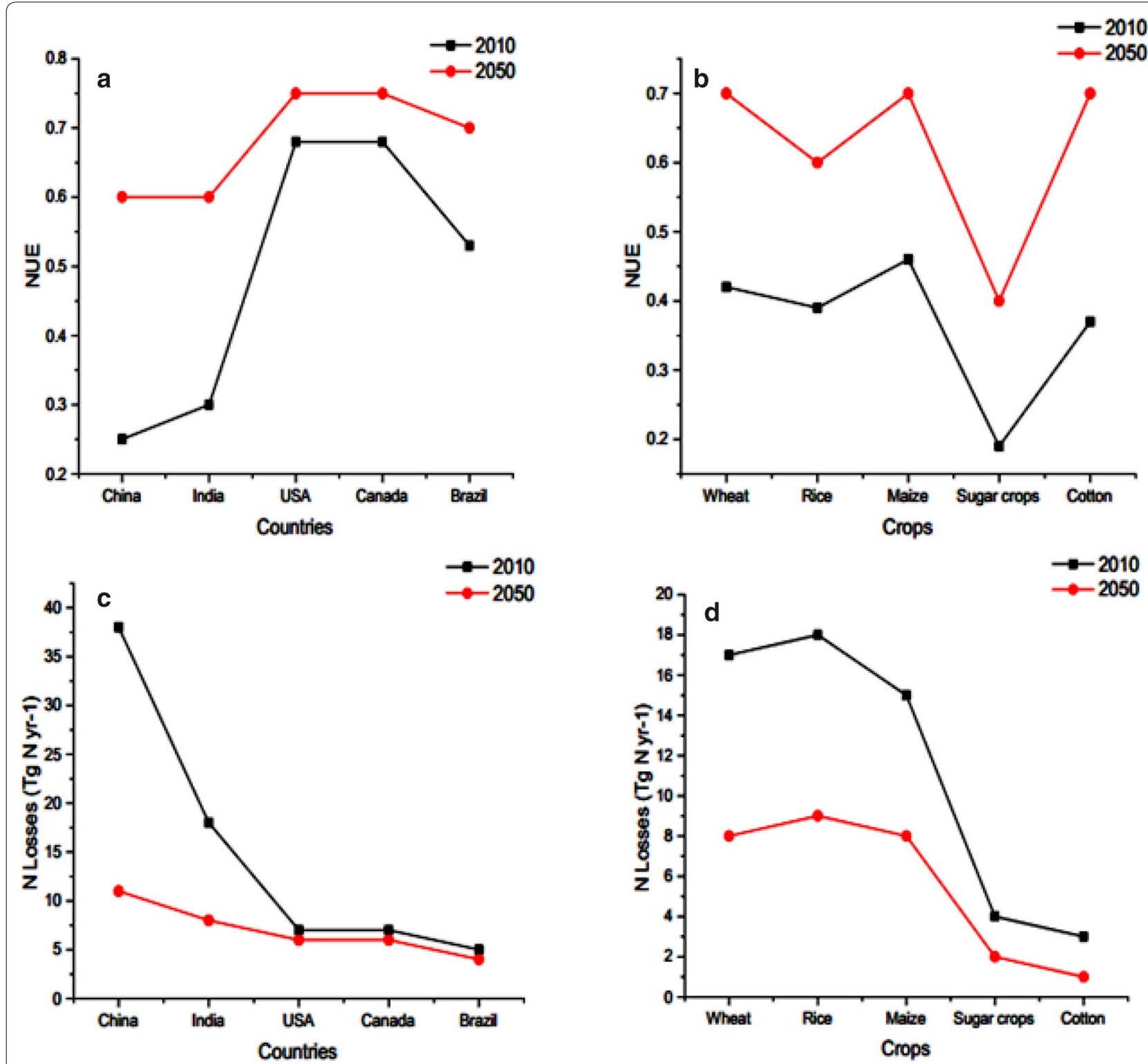

Fig. 1 This diagram depicts country wise (a) and crop wise (b) NUE for 2010 and 2050 (proposed), while c, d shows nitrogen losses in teragram for 2010 and 2050 (proposed)

leads to decrease yield in crops due to low amount of $\mathrm{N}$ available. The midseason rice NUE is less than $30 \%$ in China, which indicates that $70 \%$ nitrogen is going into the ecosystem as loss [33]. As comparison of USA and China from 1980 to 2010 for NUE in case of maize crop, the NUE declined from 30.2 to 29.9 in China but up-graded from 39.4 to 53.2 in USA [34]. Hajari et al. [35] demonstrated few varieties of sugarcane for nitrate and ammonium as a source of $\mathrm{N}$ fertilizer in their study and concluded that $\mathrm{NO}_{3}{ }^{-} \mathrm{N}$ resulted in higher NUEs as compared to $\mathrm{NH}_{4}{ }^{+}-\mathrm{N}$. Wheat and maize grown in a hydroponic culture containing $\mathrm{NH}_{4}{ }^{+}-\mathrm{N}$ showed that the photosynthetic and carbon assimilation rates decreased in the plants $[35,36]$.

\section{Available sources and forms nitrogen}

The conversion of nitrogen from one form to others greatly influences the nitrogen use efficiency.In early growth stage $\mathrm{NO}_{3}{ }^{-}$form of nitrogen is important but it has not been commonly used as fertilizers alone, the other forms go the atmosphere by nitrification [37]. However, most widely used nitrogen fertilizer urea is abruptly 


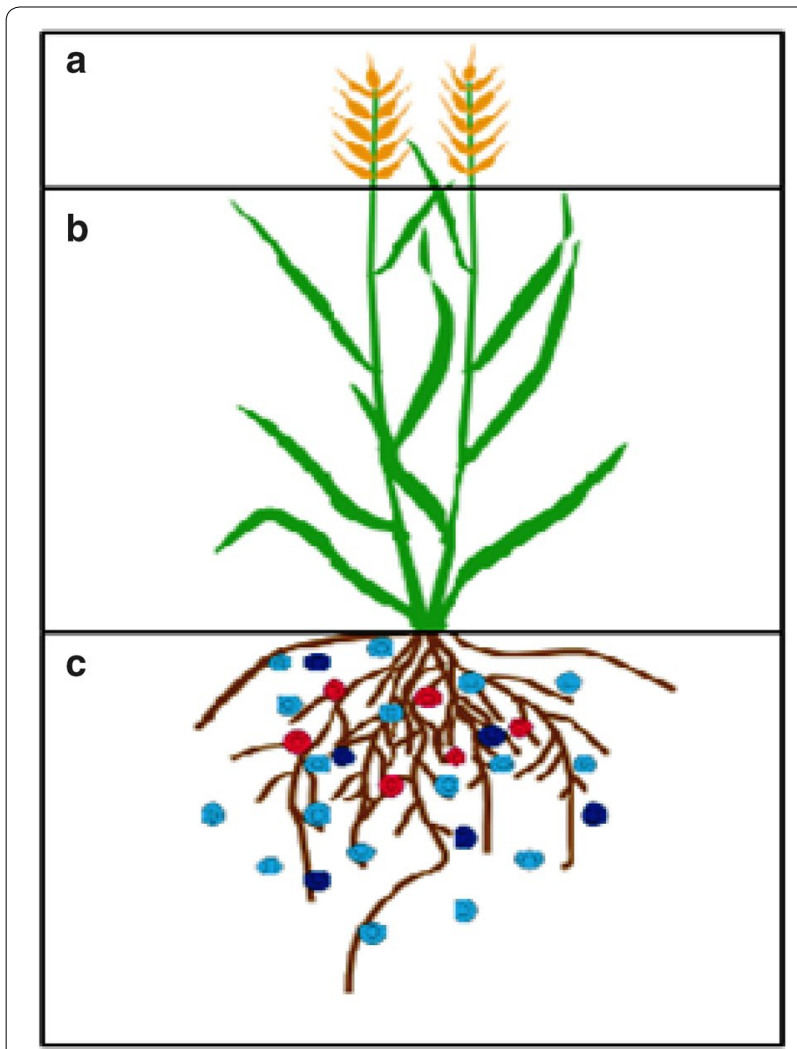

Fig. 2 The major plant pats which have their own role for NUE. a Grain: responsive to fertilizers and nutrient storage component, $\mathbf{b}$ Shoot: nutrient redistribution, assimilation and transportation (source and sink), c Roots: Efficient nutrients uptake by transporters and channels

nitrified (Fig. 4) after conversion to ammonium [37]. Although urea after application in soil can convert into nitrate and ammonium form, it is not still clear about urea uptake process and metabolic changes in plants [38]. Urea is also preferred and predominant source of $\mathrm{N}$ due to more nitrogen contents and low cost to produce it in South Africa [39].

The soil N (Fig. 3) is most important to observe the efficiency of $\mathrm{N}$ in the agricultural field conditions [40-44]. There are a lot of evidence from various field trials using ${ }^{15} \mathrm{~N}$-labeled fertilizer, $\mathrm{N}$ uptake is principally derived from soil (Fig. 3) rather than fertilizer [45-53]. However, many studies have been conducted and found that unfertilized $\mathrm{N}$ responses often give more yield than that of $\mathrm{N}$ fertilized [43, 54-56], except those in which soil $\mathrm{N}$ availability is captured by accumulation of carbonaceous residues. Total soil nitrogen and organic carbon vary in soil profile, both decreases with the soil depth, however the ionic forms of $\mathrm{N}\left(\mathrm{NH}_{4}{ }^{+}, \mathrm{NO}_{2}{ }^{-}\right.$, and $\left.\mathrm{NO}_{3}{ }^{-}\right)$ shape the mineral nitrogen dynamics because discrepant increments of mineral nitrogen stock in each soil layer takes place $[57,58]$.

According to Neto et al. [60] when nitrogen concentration increases even though it is earlier applied, mineralization of nitrogen in soil is boosted and a part of $\mathrm{N}$ shares from the mineralized nitrogen. Nitrogen within the plants at anthesis stage also enhanced due to the transformation of nitrogenous compounds, which have stored nitrogen in earlier growth period [61, 62]. Crop growth, development, biomass and yield have directly linked to nitrogen assimilation [61, 63]. Mazzafera and Goncalves [64] analyzed xylem sap to study nitrogen transformation in coffee plants and found $52 \%$ of the total nitrogen is nitrate. But nitrate reductase reduces it into nitrite [65].

Sugarcane accumulates nitrogen $100-150 \mathrm{~kg} \mathrm{ha}^{-1}$ in leaves and stalks, only about $55 \%$ is removed from stalks up to maturity [66]. The plant residues after harvesting are put into the field which gradually mineralized and release $\mathrm{N}$ in available forms [67]. Nitrogen consumption by enhanced $\mathrm{N}$ fertilization to the crop may lead to high $\mathrm{N}$ uptake but it is not necessary to increase biomass production [68]. Thus, over use of nitrogen fertilizer down-regulates the nitrogen use efficiency and increases production cost and environmental pollution.

Plants have the ability to acquire excessive $\mathrm{NO}_{3}{ }^{-}$nitrogen than the requirement for assimilation and store it in unassimilated pools like vacuoles of leaves [69], become available for utilization under low $\mathrm{N}[70,71]$. Hajari et al. [35] and Robinson et al. [37] found, the $\mathrm{NO}_{3}{ }^{-} \mathrm{-N}$ per gram was higher in dry roots than the shoot on all growing media. Hajari et al. [35] claimed that the sugarcane plant is not able to translocate $\mathrm{NO}_{3}{ }^{-} \mathrm{N}$ from root to shoot efficiently due to which limited $\mathrm{N}$ uptake and transport occur rather than assimilation which may affect the NUE in sugarcane. The application of a nutrient may increase (synergism) or decrease (antagonism) the contribution of the other nutrients in crop yield. The concentration of phosphorus and nitrogen varies over the growing period in the soil and create interaction either synergistic or antagonistic. The response of crop yield might be affected directly or indirectly $[72,73]$. Therefore, the supply of both $\mathrm{N}$ and $\mathrm{P}$ creat changes in chemical, physical, and biological properties of soil $[74,75]$. The nitrogen fertilizer has synergetic effect to phosphorus. The results indicated, addition of nitrogen along with phosphorus fertilizer produced better positive interaction than separately [76]. In the sugarcane field which has previously wild vegetation and low available phosphorus response nutrient limitations, it involves phosphorus as limiting source in high demand periods, and also microbial biomass [77-85]. 


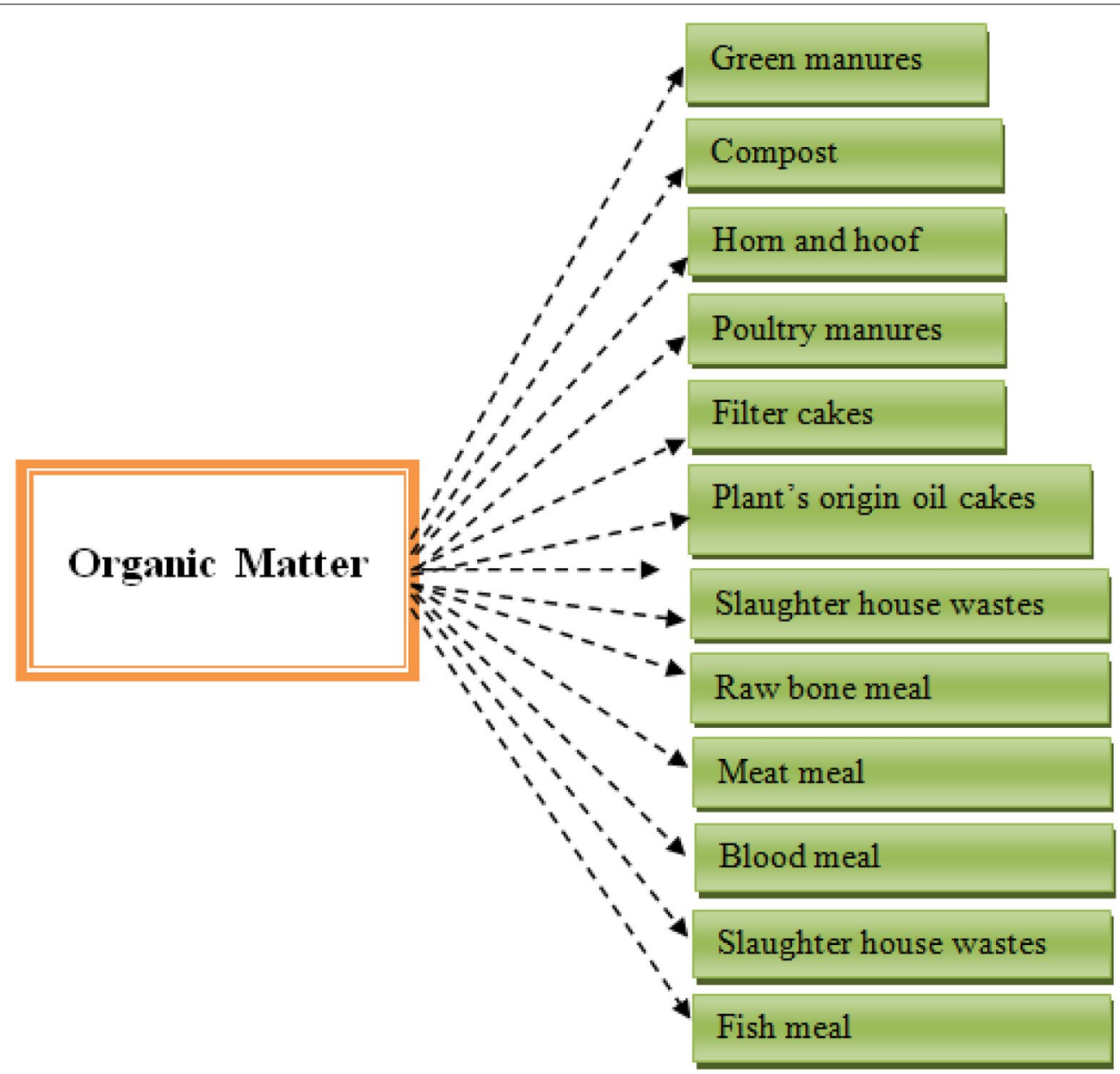

Fig. 3 Sources of organic nitrogen available for mineralization in soil [59]

\section{Losses of nitrogen in the ecosystem}

Worldwide high nitrogen fertilizer application results in economic loss and ecological hazardous due to extra consumption of resources, water eutrophication, and high rate of greenhouse gas emissions along with potential leaching. The inefficient $\mathrm{N}$ utilization with poor transformation of provided $\mathrm{N}$ results in unintentional fertilizer loss in soil, atmosphere and promoting contamination of groundwater, distort connecting biological communities and cause dangerous atmospheric deviation, through the emission of the poisonous ozone depleting substance nitrous oxide [82], eutrophication, air pollution, $\mathrm{N}$ leaching, water pollution, soil acidification and soil degradation $[14,18,82-89]$ which is not suitable for environment friendly crop production and human life (Fig. 4).

In agriculture, crop production requires plentiful $\mathrm{N}$ which is the most widely recognized limiting factor for crop growth, development and yield. A lot of synthetic $\mathrm{N}$ fertilizer is applied to arable land by growers to fulfill the demand for crop production. An abrupt increment in fertilizer applications in China was noted, and it consumed $30 \%$ of total $\mathrm{N}$ fertilizers synthesized around the world in 2002, in spite of the facts, its arable land accounts only $10 \%$ of the world aggregate. However, the use of vast amounts of synthetic $\mathrm{N}$ fertilizer to expand crop yield are not financially sustainable and put a substantial burden on farmers, and furthermore result in environmental pollution. Every crop cannot use about $50 \%$ nitrogen fertilizer during its growing season due to over fertilization [90].Moreover, plants grown under excessive nitrogen applications are more susceptible to lodging because of shoot overgrowth and tender, and pest damage and disease, and also degrade quality of the grains [91].

The $\mathrm{N}$ losses thru lixiviation, direct escape to the air, denitrification and/or percolation is higher due to over use of $\mathrm{N}$ fertilizer [92]. The synchronized application as the demand of plant at its critical stage can decrease losses of applied $\mathrm{N}$ fertilizer [93-95]. Over the last decade, crop response to $\mathrm{N}$ fertilization $[96,97]$ was detected 


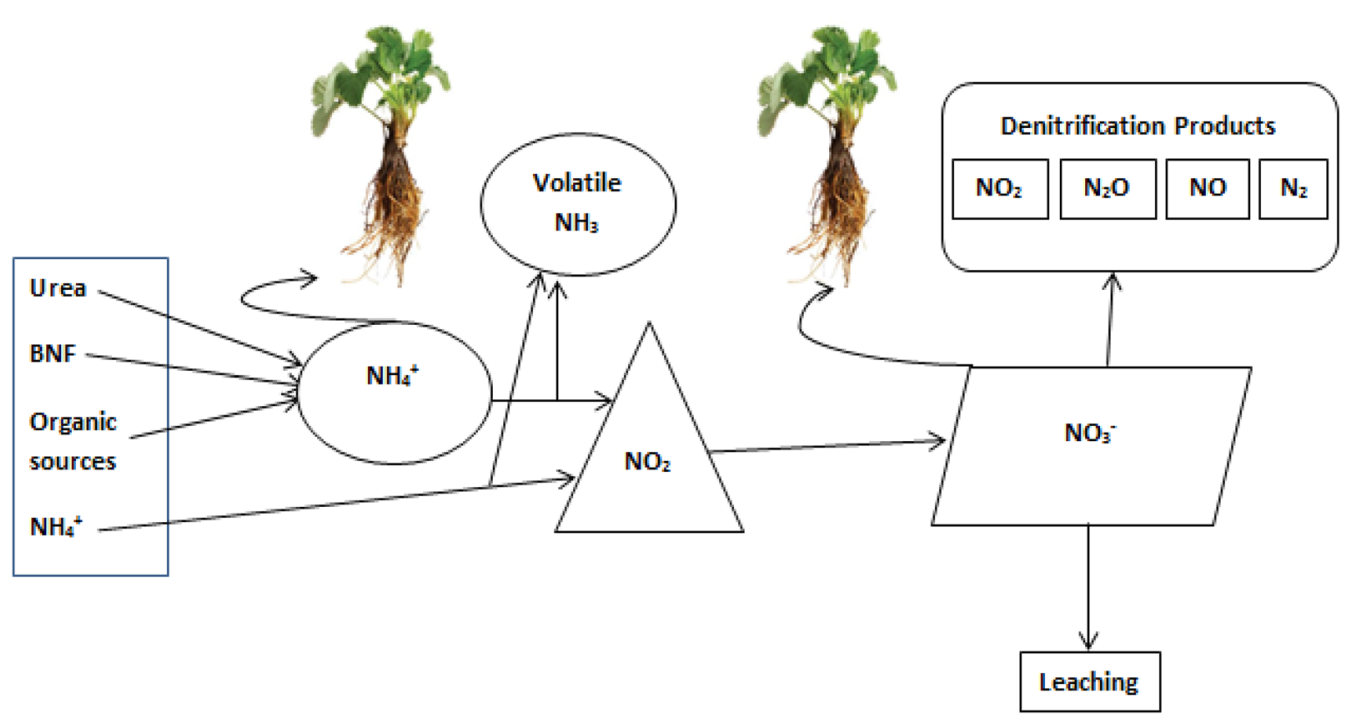

Fig. 4 Summary of nitrogen sources and, their conversion, availability to plants and losses within/outside of soil

in sugarcane fields all over the Brazil for green cane trash blanketing systems (GCTBS) and also in situ quantify $\mathrm{NH}_{3}$ volatilization [98], $\mathrm{NO}_{3}$ leaching [99-101] , and $\mathrm{N}_{2} \mathrm{O}$ emissions [102, 103], $\mathrm{N}$ use efficiency [104, 105]. About $60-80 \%$ synthetic $\mathrm{N}$ fertilizer is not taken up by sugarcane crop under GCTBS, and losses due to volatilization, denitrification and leaching has been observed, but most of the mineral $\mathrm{N}$ is not available for micro biota, while the remaining part available to the crop [96]. In spite of the fact that the mechanism of commercial fertilizers is relatively well familiar [106]. However, many researchers claim the impact of organic and organomineral is not understood on chemical and microbial properties of soil for successful crop cultivation in temperate areas [107-109].

Biotic factors like size and diversity of microbial community and abiotic factors temperature, soil moisture content, temperature have direct relation to regulate organic compounds mineralization in the soil (Fig. 3), however, seasonal climatic change during cropping season fluctuate the mineral $\mathrm{N}$ availability [110]. Rapid availability of mineral $\mathrm{N}$ in soil solution has been noted as a result of synthetic $\mathrm{N}$ fertilizer application $[96,111,112]$, but there is a powerful race between crop plants and micro flora for existing mineral $\mathrm{N}$ (especially $\mathrm{NH}_{4}{ }^{+}$), and cause a large variations over time [77, 78].

Urea is the major $\mathrm{N}$ fertilizer that is applied to the field and also the main source of $\mathrm{NH}_{3}$ gas emission (Fig. 4) from agronomic practices [113] contributing for about $20 \%$ of the emissions in Germany [114] and is highly important in many other countries like China. Nitrogen loss as $\mathrm{NO}_{3}^{-}$leaching (Fig. 4) from sugarcane field has significant contribution to pollute environment in Australia [115]. Many researchers in Brazil also find out leaching losses of nitrogen in planted sugarcane throughout its growth [116]. However, during ratoon season, $\mathrm{NO}_{3}{ }^{-}$leaching is more important than the planted cane [100]. The skips within ratoon sugarcane field increased across the growth period, and decreased the crop $\mathrm{N}$ response. The unique response to applied $\mathrm{N}$ fertilizer can be attained by well-established ratoon crop similar to planted crop density.

Duan et al. [117] discuss their findings about $\mathrm{N}$ application to long and short vines of sweet potato, the both long-vine and short-vine cultivars have the peak yield for nitrogen applied as 30 and $90 \mathrm{~kg} \mathrm{ha}^{-1}$ respectively. The cultivars of same production potential have reduced their yields, and the root yield of long vine is significantly lower than that of short vine for nitrogen $120 \mathrm{~kg} \mathrm{ha}^{-1}$. Wu et al. [118] also claim the cultivar Zijing No. 2 decrease in the root yield for $\mathrm{N}$ application $\left(75 \mathrm{~kg} \mathrm{ha}^{-1}\right)$ in fertile soil. Thus, the genotypic differences in sweet potato have a great influence on the partitioning of dry matter as well as uptake of nitrogen [119]. Wilson [120] classified cultivars of sweet potato for $\mathrm{N}$-responsiveness, nonresponsive and depressive natures. Nitrogen buildup and distribution for short stature tuber roots are greater, and similarly exhibit more yield in response to high $\mathrm{N}$ conditions [121]. Besides, the cultivars that require higher $\mathrm{N}$, give higher root yield in fertile soils [118].

Total nitrogen fertilizer can be reduced up to $360 \mathrm{~kg} \mathrm{ha}^{-1}$ with respect to $430 \mathrm{~kg} \mathrm{ha}^{-1}$ for cropping system based on the wheat-maize rotations, along with improved agronomic practices. It was resulted in 
increase in maize yield by $7-14 \%$, but reduction in wheat yield, $\mathrm{N}_{2} \mathrm{O}$ and $\mathrm{NO}$ emissions by $1-2 \%, 7 \%$ and $29 \%$, respectively [122]. In addition, best fertilization practices are an option to improve NUE and also seasonal collective $\mathrm{N}_{2} \mathrm{O}$ emission decrease [123]. Leaching process can be minimized by adopting legume crops in cropping system up to $50 \%$ than the conservative systems [124]. Soybean reduces $50-60 \%$ of $\mathrm{N}$ demand by biological nitrogen fixation [125]. Graham et al. [126] and Resende et al. [127] observed that addition of synthetic fertilizers decreased soil N stocks, while Ladha et al. [108] reported an increase in soil $\mathrm{C}$ pool and $\mathrm{N}$ stocks for long-term organic fertilizer application.

\section{Agronomic and physiological approaches Application rates}

Irrational application of nitrogen is a major problem of low nitrogen use efficiency [128-130]. Therefore, agronomic principles and practices should utilized in modern techniques to enhance nitrogen use efficiency, so as the reduced application rate of fertilizer inputs without yield reduction is key factor [32]. Soil characteristics and agro-climatic conditions highly force the application level of fertilizer [131]. Crops can use only up to $35 \%$ of the supplied $\mathrm{N}$ during its complete life cycle [39] and the remaining is escaped to the environment by various mechanisms and functions (Fig. 4) [132, 133].

Improvements in NUE by decreasing nitrogen dose may delay leaf senescence which results in no yield loss. Late-season leaf senescence due to low nitrogen application rate provides relatively higher photosynthetic capacity to crop and ultimately increase yield production. Mulvaney et al. [109] proposed N mineralization in soil is positively regulated by synthetic nitrogen fertilizer. These findings indicate that $\mathrm{N}$ may exceeds the demand of sugarcane crop $\left(200 \mathrm{~kg} \mathrm{ha}^{-1}\right.$ year $\left.^{-1}\right)$ and affect $\mathrm{C}: \mathrm{N}$ ratio in soil for long time continuous applications.

Srivastava and Suarez [134] confirmed N recommendation rate for sugarcane varies worldwide for 45 to $300 \mathrm{~kg} \mathrm{ha}^{-1}$ but 60 to $140 \mathrm{~kg} \mathrm{ha}^{-1}$ is recommended for Brazil. Dametie and Fantaye [135] summarised the results of sugarcane $\mathrm{N}$ uptake studies by various researchers in the globe, and indicated that the usual need of ratoon crop for nitrogen is $1.5 \mathrm{~kg} \mathrm{Mg}^{-1}$ cane yield. $\mathrm{N}$ uptake varied from 0.88 to $1.47 \mathrm{~kg} \mathrm{Mg}^{-1}$ in Hawaii, and stubble cane production required $1.3 \mathrm{~kg} \mathrm{Mg}^{-1}[136,137]$. By the compilation of numerous results for nitrogen dosage and technically recommendations in Brazil, the usual rate is $1.0-1.4 \mathrm{~kg} \mathrm{Mg}^{-1}$ cane [138].

Nitrogen fertilizer application dose can be minimized by $20 \%$ without yield loss in Australia [139]. The N fertilizer in China has possibility to use moderately at low rate by integration management practices [140]. The reports from different regions/countries suggest that $\mathrm{N}$ use efficiency can increased by decreasing $\mathrm{N}$ application rate [141-144]. However, it also depends on agronomic traits, fertility of soil, management and yield potential [141-144].

The $\mathrm{N}$ application rate can also be determined by vegetative growth and productivity index, for example, coffee plants showed high rates for it between 2400 and $3600 \mathrm{~kg} \mathrm{ha}^{-1}$ per year $[60,145]$ and $\mathrm{N}$ as urea applied 600 to $800 \mathrm{~kg} \mathrm{ha}^{-1}$ to maintain this productivity in Brazil. Official recommendations for nitrogen fertilizer are $400 \mathrm{~kg} \mathrm{ha}^{-1}$ year $^{-1}$ [61] and apply in tow or four splits. But the coffee growers applied urea between 600 and $800 \mathrm{~kg} \mathrm{ha}^{-1}$ in 26 splits during coffee cycle. In fact, they attempted this practice to stop $\mathrm{N}$ deficiency, but causing low nitrogen use efficiency [146]. Luo et al. [32] suggests that $20 \% \mathrm{~N}$ can be reduced, when plant density is high, without yield loss and also can reduce for drip fertigation.

\section{Application methods}

The international plant nutrition institute is convincing the best agronomic practices, $4 \mathrm{R}$ nutrient application principles, i.e. source of fertilizer, rate, time and site/place [147]. Soil fertility varies with in the field abruptly which has strong impact on yield and nutrient uptake by cultivated crops, and this major problem can be handled by adopting site-specific nitrogen fertilization. Site-specific $\mathrm{N}$ fertilization provides significant impacts in terms of economy and ecology in heterogeneous fields [148-150] which results in enhanced yield, quality and ultimately high nitrogen use efficiency.

Spectral measurement is a suitable approach to know the nitrogen requirements of crops and site-specific application for precise farming [151]. The principle behind laser-induced chlorophyll fluorescence (LICF) is used to the measure the $\mathrm{N}$ situation of the crop stand by close distance [152] as well as $3-4 \mathrm{~m}$ [153]. The plant nitrogen is measured indirectly by chlorophyll content via fluorescence signals ratio at 690 and $730 \mathrm{~nm}[154$, 155]. It indicates that high amount of chlorophyll resulted in lower fluorescence radiation ratio F690/F730 because reabsorbed radiations have more strength at $690 \mathrm{~nm}$. Rubisco acts as the sink of $\mathrm{N}$ and has close relation to chlorophyll content, thus the ratio F690/F730 describes the $\mathrm{N}$ content of the plant [156].

Crop canopy sensor calibration is too sensitive to field variability like the ramp calibration strip [157] or the calibration plot methods [158]. The reference area for canopy sensor within a field should be given according to field and soil variability [159] that also relates to the sugarcane plant density variation. The calibration should be done for every crop and season, separately [160]. Yong 
et al. [161] applied nitrogen fertilizer at various concentrations among the rows of maize-soybean relay intercropped field at three different distances $(15 \mathrm{~cm}, 30 \mathrm{~cm}$ and $45 \mathrm{~cm}$ ) and concluded that crop performed better for $15 \mathrm{~cm}$ and $30 \mathrm{~cm}$ treatments. The NUE and total grain yield of the maize-soybean relay intercropping system were significantly higher in $15 \mathrm{~cm}$ and $30 \mathrm{~cm}$. So, lower $\mathrm{N}$ application at $15-30 \mathrm{~cm}$ from fertilizer application location to the maize row was optimal.

Productivity of low land rice has a great dependence on the selection of varieties and their nutrient utilization capacity. Under dose of $\mathrm{N}$ fertilizer may happen, especially when $\mathrm{N}$ is subject to immobilization following ratoon crop fertilization for unburned sites [56]. Crop response to inputs is also influenced by climate, for example, high altitude of Andhra Pradesh is endowed with the special soil and climate where varietal responses to inputs vary relatively to coastal plains. Different nitrogen sources should be jointly applied to fulfill the requirement of nitrogen to improve crop productivity [162].

The supply of $\mathrm{N}$ fertilizer to sugarcane is affected by soil profiles that are hard to measure inside the agricultural land [53]. Indeed, even the selection of reference regions, that get satisfactory measures for nitrogen, according to Raun et al. [163], can be risky with regards to evaluating sugarcane $\mathrm{N}$ feedback; depending upon where reference zones were set up, the harvest $\mathrm{N}$ reaction can differ altogether. For instance, producers may realize that a yield did or did not respond to $\mathrm{N}$ application, and such conflicting results found in various experiments were demonstrated by Duan et al. [117]. Hence, use of canopy sensors to quantify the $\mathrm{N}$ response is troublesome because of variable plant density inside the fields. In that capacity, different elements can veil the $\mathrm{N}$ impacts, like soil compaction, pest attack and diseases. Zillmann et al. [164] announced a comparative issue when they conducted a test for $\mathrm{N}$ connected to maize. For all the experimental area, the crop response for $\mathrm{N}$ was not similar as proposed.

The canopy sensor has to be utilized when the sugarcane tallness is between 40 and $70 \mathrm{~cm}$ to get estimation affectability to sugarcane vigor fluctuation $[165,166]$. At this stage, sugarcane has attained around $10-30 \%$ of total biomass with $27-68 \% \mathrm{~N}$, which is dependent on genotype, soil fertility, climate and developmental stage [167]. $\mathrm{N}$ requirement of crop prior to treatment can achieved by various sources, i.e. mineralization of organic sources and endophytic nitrogen fixation by bacteria related to plant roots [53, 168-170], and also other inputs to the field like vinasse, poultry manure and farmyard manure etc.

\section{Drip fertigation}

Northwestern China has an arid climate, cotton production in this region is not possible without irrigation and $\mathrm{N}$ fertilization [171]. Drip fertigation is a good option to supply water and fertilizers in precise quantities [172, 173]. Drip fertigation with mulching is going to be extensively used in recent years [174]. It is well documented that the nutrient and water use efficiency both can be enhanced through drip fertigation that improves crop production for each unit of nutrients and water [172, 175]. It has more advantage of the soluble fertilizers that can be put in specific quantity alongside the good crop health and potential yield because of maintained fertigation in the root zone [173]. Many studies pointed out fertigation can improve fertilizer use efficiency by decreasing application rates without losing crop yield $[176,177]$ and especially drip fertigation of cotton field with reduced nitrogen, improved its efficiency $[175,178]$. It improved cotton yield, yield components, and leaf area index (LAI) by 20 to $30 \%$ as compared to furrow irrigation [179]. However, maximum nitrogen recovery was obtained by sacrificing cotton yield at lower $\mathrm{N}$ level under drip fertigation [180]. So, an optimum $\mathrm{N}$ level for drip fertigation has important role to achieve highest cotton yield.

Traditional high nitrogen application without considering method of application and plant population gives more seed cotton yield. Anyhow, N can be reduced up to $15-30 \%$ when drip fertigation is employed and $20 \%$ in case of high plant population without sacrificing seed cotton yield. The findings of Luo et al. [32] are that $\mathrm{N}$ reduction up to $30 \%$ has non-significant seedcotton yield reduction for drip fertigation. However, drip fertigation shows increase by 5 and $20.7 \%$ in seedcotton yield for 15 and $30 \%$ nitrogen reduction.

In other words, drip fertigation with high plant population is an important attribute to save nitrogen with sustainable yield for arid culture. Many experiments have conducted to find agronomic practices, high planting density, diversified planting geometry [181] organic fertilizers and improvement of application method of nutrients are helpful to regulate cotton yield for reduced nitrogen conditions in the Yellow River valley, China [11, $12,140]$.

\section{$\mathbf{N}$ and plant density}

The plant density is an important tool to testify $\mathrm{N}$ rate without sacrifice of yield either by increase or decrease in number of plants per unit area [12, 140, 182]. It varies active crop canopy reflectance on the base of ground for sensors [183]. This idea has been proficiently utilized to control $\mathrm{N}$ application for rice [121], maize [184-188], cotton [189] and wheat $[188,190,191]$. The application of 
nitrogen based on canopy sensor depends on chlorophyll of crop canopy which describes nitrogen status [192], but it is not as valid for sugarcane. The field-scale sensor observations at the leaf level poorly show a relationship with nitrogen and chlorophyll status [166]. It is due to irregular sugarcane canopy which may show ground soil to the sensor. Dynamic and manually monitored canopy reflectance sensors are available, which consider all the parameters for sugarcane biomass variation, principally effected by plant population, as described by Amaral et al. [138].

Amaral et al. [138] conducted strip experiments for different nitrogen rates and validated that the uniform distribution of canopy has no trouble for canopy sensor. Variation in the canopy is mainly affected by plant population and vigor rather than the nitrogen supply. Six trials with differing nitrogen supply were conducted at different locations, five out of six trials has non-significant response to variable nitrogen supply and the sixth trial may have variation in soil characters, deeper root zone and more water holding capacity, therefore increases soil nutrient utilization and crop vigor.

\section{Intercropping}

Intercropped crops are significantly influenced by fertilization methods and show better growth for diverse nitrogen supply for interspecific rows instead of intraspecific [193]. Interspecific applications accelerate resource use efficiency, soil productivity and also have positive impacts on the environment [194-197]. This system involves more than one crop in a season, and can be observed in the Huang Huai Hai, China [198], and relay intercropping system is common in the Southwest China where one crop or three crops in 2 years are grown [199]. So, better nitrogen fertilization methods and relay or intercropping systems based on soybean (legume crop) greatly influenced on soybean yield with decreasing environmental cost. But environmental features like rainfall, light intensity and heat can be limiting factors for cropping systems. Maize-soybean relay intercropping occupies largest planting area in Southwest China that is helpful to improve nitrogen, light use efficiencies and soil nutrient availability [20, 199-204].

There are many previous studies indicating that high $\mathrm{N}$ input has undesirable outcome for biological nitrogen fixation [205]. When nitrogen availability studied for legume-nonlegume mixtures, high content of mineral nitrogen in soil triggers the microbial nitrogen fixation and hence availability of nitrogen decrease for nonlegume crop [206]. However, low input of nitrogen increased significantly fixation and stimulated the translocation of fixed $\mathrm{N}$ to nonlegume [203, 207].

\section{NUE regulating enzymes and genes}

The major sources of nitrogen, taken up by higher plants, are nitrate and ammonium as synthetic fertilizers, organic compounds and amino acids etc. It depends upon the availability of nitrogen, and within the plants it is controlled by many metabolic pathways and genes expression levels [208]. Nitrogen use efficiency is dependent of soil nitrogen conditions, photo synthetically fixed carbon dioxide to provide precursor for biosynthesis of many amino acids and vice versa $[209,210]$. It has been also claimed that all the inorganic nitrogenous fertilizers first converted to ammonium before uptake by higher plants [211]. Nitrate reduction occurs in roots as well as shoots but nitrate reduced directly in cytoplasm while in plastids/chloroplast via nitrite [208]. Reduction of nitrate to nitrite occurs in cytosol by nitrate reductase enzyme (Table 1) [212]. Nitrite is transported into chloroplasts in leaves where nitrite is converted to ammonium ions due to nitrite reductase (Table 1) [213]. The products of ammonia, glutamine and glutamate, act as donor of the nitrogen during biosynthesis for nucleic acid, chlorophyll and amino acids. The isoenzymes of glutamine synthetase, glutamate synthase, and glutamate dehydrogenase (Table 1) have been proposed for three major ammonium assimilation processes: primary nitrogen assimilation, reassimilation of photorespiratory ammonia, and "recycled" nitrogen [213]. Organic nitrogen in

Table 1 The basic information of enzymes involved in nitrogen metabolism of plants

\begin{tabular}{llcl}
\hline Enzyme & Abbreviation & Encoding genes & Function \\
\hline Nitrate reductase & NR & 5 & Reduce nitrate ion into nitrite ion \\
Nitrite reductase & NiR & 30 & Further reduce nitrite into ammonium ion \\
Glutamine synthetase & GS & 49 & Involve in GOGAT pathway \\
Glutamine oxoglutarate aminotransferase & GOGAT & 15 & Involve in GOGAT pathway \\
Glutamate dehydrogenase & GDH & 3 & Dehydrogenate a-ketoglutarate \\
Aspartate aminotransferase & AST & 13 & Catabolise glutamate into aspartate \\
Asparagine synthetase & AS & 4 & Aspartate is converted into asparagine \\
\hline
\end{tabular}


the form of amino acids transferred from source organs to sink (Fig. 2), for example, glutamine and glutamate can be used to form aspartate and asparagine [211, 214]. The ammonium nitrogen is transferred into amino acids by the enzymes e.g. glutamine synthetase, glutamate synthase, asparagine synthetase and aspartate amino transferase (Table 1). The coherent situation existed for glutamate dehydrogenase either it is involved in assimilation of ammonium nitrogen or carbon cycling $[215,216]$.

The ammonium assimilating enzymes are important during grain filling stage due to its remobilization. The biosynthesis of amino acids from ammonia is occurred by the GS and GOGAT pathways (Fig. 5) [217]. Nitrogen reutilization is an important phenomenon involving NADH-GOGAT enzyme, rice grain weight increased up to $80 \%$ due to over production of NADH-GOGAT [218]. Glutamine dehydrogenase involves for senescing of leaves and also controversy as deaminating (Fig. 5) [219, 220] and aminating directions [23]. Young leaves recycle nitrogen from chloroplast by GS2 and Fd-GOGAT. In GOGAT catalyzed proteolysis, GS2 and de facto NiR are responsible for breakdown of chloroplast during senescence. Production of glutamine during leaf senescence is basically dependent on GS1 isoform. Substrates for GDH are produced from chloroplast proteins proteolysis, and deaminating activity provides 2-oxoglutarate and ammonia. Glutamine for new sink organ is produced by GS1 reassimilation of ammonia [221].
Each monomer of homodimer nitrate reductase associated with three prosthetic groups: flavin adenine dinucleotide (FAD), a molybdenum cofactor (MoCo) and a haem. NR reduces chlorate into toxic chlorite, responsible gene for that in mutant has been identified, the Nia genes encoding the NR apoenzyme and the Cnx genes encoding the MoCo cofactor. [208, 222]. The Nii genes have one to two copies encoding the NiR enzyme [208]. GS having decameric structure is controlled by two classes of genes, GLN1 and GLN2, [223]. GLN2 (single nuclear gene) encodes chloroplastic GS2, involved in ammonium assimilation or re-assimilation either from nitrate reduction in $C_{3}$ and $C_{4}$ plants or photorespiratory product of $\mathrm{C}_{3}$ plants [224]. On the other hand, GS1 isoform is encoded by GLN1 gene family which recycles ammonium during leaf senescing and transport in the phloem sap [225]. Vanoni et al. [226] reported that GOGAT (mechanistic structure) has two forms Fd GOGAT (in leaf chloroplast) and NADH GOGAT (in plastids of non-photosynthetic tissues). Three genes (ASN1, ASN2 and ASN3) encode asparagine synthase, and substrate ammonia is utilized by asparagine synthase to form asparagine [227]. Storage compounds, long-range transporter and glutamine has lower $\mathrm{N} / \mathrm{C}$ ratio than asparagine $[228,229]$. In plastids; bicarbonate, adenosine tri-phosphate and amide/ ammonium from glutamine act as substrate for carbamoylphosphate synthase (CPSase) to form precursor (carbamoylphosphate) of citrulline and arginine.

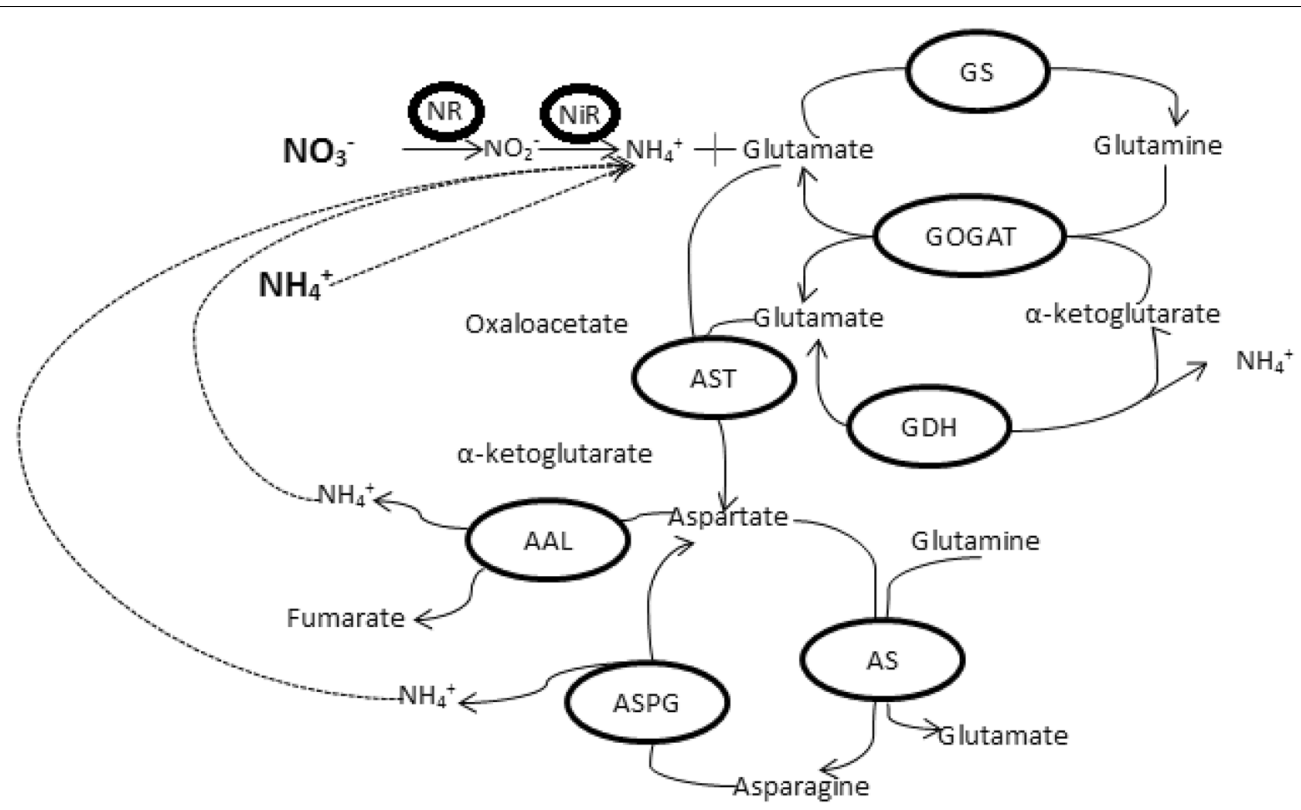

Fig. 5 Schematic diagram to show the fate of nitrogen within the plant Bolded $\mathbf{N O}_{3}^{-}$and $\mathbf{N H}_{4}^{+}$are nitrogen uptake forms by roots through different transporters 
The subunits (small and large) of carbamoylphosphate synthase (CPSase) encoded by car $A$ and $B$ genes, respectively [230]. Finally, glutamate is produced by mitochondrial NADH-glutamate dehydrogenase for higher levels of ammonium [23].

\section{NUE responsive genes manipulation}

Crop varieties that are highly $\mathrm{N}$ efficient, high yields with reduced $\mathrm{N}$ input is the main solution for improving NUE [231-233]. Recent studies documented that shoot-to-root signaling pathways, feedback mechanisms and amino acids transportation in roots and shoots influence the nitrogen uptake and its metabolism [234238]. With the aim of improving NUE, approaches have been adopted on the basis of genetic changes for nitrogen uptake [239-241], nitrate allocation [242], nitrogen metabolism [218, 243-249] and the regulation [250].

Many critical candidate genes also have been overexpressed and knocked out in order to test for biomass and plant nitrogen status. Nitrate influx increased due to over-expression of HATS-like NRT2.1 but at the same time NUE and its utilization phenotypically remains unchanged [46]. Overexpression of genes encoding for $\mathrm{NR} / \mathrm{NiR}$ in transgenic plants to improve NUE has no surety for its utility. Nitrate reductase related gene overexpression in tobacco plants showed delayed NR-activity for drought conditions and quick recovery for re-watering after short time drought [251]. It has been observed that nitrate level decreased in transgenic Arabidopsis, tobacco and potato plants without improving in biomass, number of tubers and seeds respectively. Regardless of the nitrogen available sources, Nia or Nii genes overexpression improved mRNA levels besides $\mathrm{N}$ uptake affect without any change in the yield and growth, indicating the composite post-transcriptional regulation of NR [252].

When we talk about GS1 and GS2 genes expression, the overexpressed GS2 has been testified along with Rubisco promoter in Nicotiana tabaccum and CaMV $35 \mathrm{~S}$ promoter in Oryza sativa [4, 217]. It enhanced growth rate in Nicotiana tabaccum and photorespiration and drought tolerance in Oryza sativa. Overexpression of GS1 genes with promoters having different combinations, RolD, CaMV 35S and Rubisco subunit (rbcS) have been reported with positive results for plant biomass and grain yield. For example, grain yield and roots are significantly higher with more $\mathrm{N}$ content in nitrogen efficient wheat lines under the control of the rbcS promoter observed [248]. Similarly, biomass and leaf protein in Nicotiana tabacum (over expressed GS1) increased under the control of CaMV 35 S promoter [253]. Another overexpression of GS1 gene depicted 30\% increase in yield of maize due to more kernel number and size [231].
In conclusion, GS activity has direct relation with biomass or yield in transgenic plants [254]. Over-expression of NADH-GOGAT increased in grain yield for transgenic rice plant [231]. So, it is important to know the alleles of genes and promoters to improve yield by overexpressing GS or GOGAT genes. Overexpressed ASN1 in Arabidopsis increased soluble protein content in seed, total protein and plants ability to grow for limited nitrogen supply [229]. These results suggested that NUE can be improved by manipulating downstream steps in $\mathrm{N}$-remobilization. Further studies of carbon metabolism pathways also have potential to improve NUE [255-257].

Several external and endogenous factors influenced the expression of genes which are highly regulated at the transcriptional as well as post-translational levels [208]. Lea et al. [218] demonstrated that post-translational regulation affects the amino acids, ammonium, and nitrate levels, whereas transcriptional regulation has only minor influence. Plants unregulated for NR accumulate high concentrations of asparagine and glutamine in leaves. Thus further characterization can provide the useful properties for crops.

Asparagine synthetase (AS) encoded by a small gene family, catalyzes the formation of asparagine (Asn) (Fig. 5) and glutamate from glutamine (Gln) and aspartate [258]. The role of AS and GS interaction in primary $\mathrm{N}$ metabolism is very crucial $[259,260]$. GS negatively correlates with the AS transcript levels and polypeptides in the transgenic plants suggesting that AS showed compensation for GS ammonium assimilatory activity [260, 261]. It is hypothized that AS might be important in regulation of the reduced $\mathrm{N}$ flux into plants due to decreased GS activity. However, the GS is essential to synthesize Gln for biosynthesis of Asp via NADH-GOGAT and AspAT [260]. Lam et al. [229] demonstrated the results of overexpressed the ASN1 gene in Arabidopsis as enhanced soluble seed protein content, total protein content with better growth on $\mathrm{N}$-limiting medium. However, in case of ASN2 gene endogenous ammonium accumulation was less compared to wild-type plants as growing on 50-mM ammonium medium [22]. Signaling processes are attractive clues for metabolic engineering. Physiological activity of glutamate dehydrogenase $(\mathrm{GDH})$ is still unclear as compared to GS/GOGAT enzymes [215]. Ameziane et al. [241] investigated GDH activity in transgenic tobacco plant, and the biomass production increased in $g d h A$ transgenic plants without considering growing conditions either controlled conditions or field.

\section{Microarray and whole genome sequencing}

It has been observed that $\mathrm{N}$ uptake remains constant throughout domestication of extraordinary maize varieties but utilization of $\mathrm{N}$ enhanced, which support the 
hypothesis of conventional breeding programs improving NRE capacity [262]. Interestingly, inconsistency of overexpressed key enzymes (NR, NiR, GS, and GOGAT) for an improvement of NUE or phenotypic change is also a challenge [218, 231, 254, 262]. Due to these reasons, new molecular techniques like microarray and transcriptome (Fig. 6) are consider as emerging tools to study the response of plants whole genome.

The arrangement of known and unknown DNA samples on a solid support is known as microarray. Every microarray contains thousands of spots, each has less than $200 \mu \mathrm{M}$ diameter and called probe [263]. These arrays may be in different formats and also probes can be smaller as oligonucleotides, cDNA or genomic sequences. Different techniques (photolithographic, nib, pin or inkjet) are employed to format. The probes are labelled radioactively or fluorescently and hybridization controlled electronically [264].

Whole genome sequencing is a modern approach to understand the changes at genomic level, expression level of genes and specific genes related to the desired traits. Good quality genome sequence information of ideotype rice and Arabidopsis plants are available for microarray analysis, but the transcriptomic profiling (Fig. 6) for whole genome sequencing of RNA is an excellent emerging technology for all plants [265, 266]. Molecular and physiological techniques have been employed in last two decades to know the differentially expressed genes (DEGs) in Oryza sativa [267, 268], Sorghom bicolor [269], Glycin max [270] and Camilia sinensis [271] for low nitrogen levels. Past studies mostly relied on single genotype for genes expression all over the world for low and normal nitrogen conditions either for nitrate or ammonium [267-271]. However, two genotypes of Camilia sinensis were studied and compared for both levels of nitrogen in ammonium form. Genotypic contrast for global genes expression and comparative analysis helped to compact the knowledge of candidate genes for NUE. A lot of information in literature regarding quantitative trait loci (QTLs) responding NUE are also available [272-274]. The combination of DEGs and QTLs datasets has great importance to develop new nitrogen use efficient genotypes in future [275].

Recent next generation sequencing technologies for transcriptomic profiling are helpful to understand the genes transcription and regulation of transcripts at all levels [276]. Illumina's RNA-sequencing platform was used for transcriptomic exploration of genes expression to investigate the response of nitrogen nutritional stress in plants. It has been reported that the amino

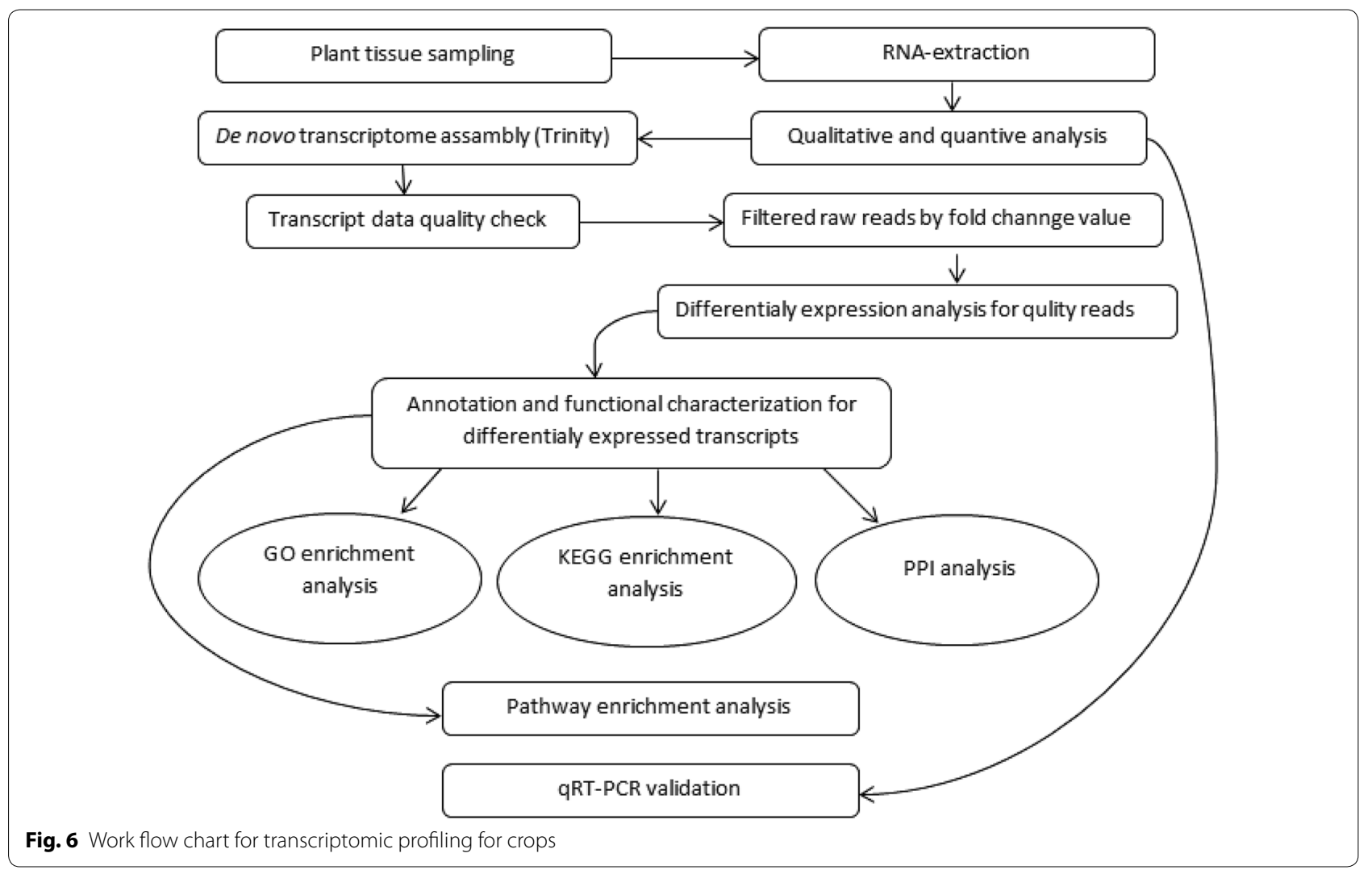


acid transporters in wheat plants play important role to transport nitrogen for development and a biotic stress conditions [277]. Based on the transcriptomic profiling Dai et al. studied the regulatory mechanism for storage protein in wheat grain in response to nitrogen supply during grain development [278]. Asparagine has crucial importance for nitrogen uptake in roots and considered as ideal nitrogen transporting molecule [258, 279, 280]. According to Curci et al. genes encoding asparagine were down regulated in leaves and roots of durum wheat under limited nitrogen [276]. It has been clearly observed that genes were down regulated in roots and leaves which were involved in carbon, nitrogen, amino acid metabolisms, and photosynthetic activity for plants grown under nitrogen free conditions [268].

\section{Conclusion}

The agronomic and molecular approaches altogether have potential to improve nitrogen use efficiency. Nitrogen losses can be minimized by precision agriculture, cut off nitrogen dose, intercropping of legume and nonlegume crops, improving plant populations and introducing nitrogen efficient genotypes. Although the studies have been conducted to improve nitrogen use efficiency of many crops by manipulating single or more genes but now the advanced technologies like whole genome sequencing are more important for future studies. Molecular breeding instead of conventional breeding is going to be more popular as of advancement in technologies. Wild genotypes are another option to improve NUE due to their more resistance against diseases, insect pest and have yield potential.

\section{Abbreviations}

N: Nitrogen; NUE: Nitrogen use efficiency; NUtE: Nitrogen utilization efficiency; $\mathrm{NU}_{\mathrm{p}} \mathrm{E}$ : Nitrogen uptake efficiency; aNUE: Agronomic nitrogen use efficiency; ATP: Adenosine triphosphate; PCR: Polymerase chain reaction; NRE: Nitrogen recovery efficiency; $\mathrm{NO}_{3}{ }^{-}$: Nitrate; $\mathrm{NH}_{4}{ }^{+}$: Ammonium; NR: Nitrate reductase; NiR: Nitrite reductase; GS: Glutamine synthetase.

\section{Acknowledgements}

The authors would like to thank the Mr. Babar Usman and Wajid Saeed for their help and support.

\section{Authors' contributions}

MA wrote the abstract, introduction and get ideas, QL and XPZ designed the figures, KKV and MAS did proof reading, FL, Z-LC and AM give their ideas to adjust the contents, $L Y$ and $Y R L$ gave main idea. $Y-R L$ revised and finalized the manuscript. All authors read and approved the final manuscript.

\section{Funding}

The present study was supported by National Key R\&D Program of China (2019YFD1000503) and Guangxi Special Fund for Scientific Base and Talent (GKAD17195100), Guangxi Sugarcane Innovation Team of National Agricultural Industry Technology System (gjnytxgxcxtd-03-01), and Fund for Construction of Guangxi Key Laboratory of Sugarcane Genetic Improvement (2019), Guangxi Ctop Genetic Improvement and Biotechnology Laboratory
(2020) and Fund of Guangxi Academy of Agricultural Sciences (2015YT02). The funding bodies played no role in the design, execution, interpretation of the data, or writing of the manuscript.

Availability of data and materials Not applicable.

\section{Ethics approval and consent to participate}

All applicable international, national, and/or institutional guidelines were followed.

\section{Consent for publication}

All authors of this paper consent for publishing manuscript and figures in this journal.

\section{Competing interests}

All authors declared no conflict of interest.

\section{Author details}

${ }^{1}$ College of Agriculture, Guangxi University, Nanning 530005, China. ${ }^{2}$ Key Laboratory of Sugarcane Biotechnology and Genetic Improvement (Guangxi), Ministry of Agriculture/Guangxi Key Laboratory of Sugarcane Genetic Improvement, Sugarcane Research Institute, Guangxi Academy of Agricultural Sciences, Nanning 530007, Guangxi, China. ${ }^{3}$ Crop Sciences Institute, National Agricultural Research Centre, Islamabad, Pakistan. ${ }^{4}$ Guangxi Crop Genetic Improvement and Biotechnology Laboratory, Nanning 530007, China.

Received: 17 December 2019 Accepted: 20 September 2020

Published online: 16 October 2020

\section{References}

1. Frink CR, Waggoner PE, Ausubel JH. Nitrogen fertilizer: retrospect and prospect. Proc Natl Acad Sci. 1999:96:1175-80.

2. Crawford NM, Forde BG. Molecular and developmental biology of inorganic nitrogen nutrition. Arabidopsis Book. 2002;1:e1.

3. Stitt M, Krapp A. The interaction between elevated carbon dioxide and nitrogen nutrition: the physiological and molecular background. Plant Cell Environ. 1999;22:583-621.

4. Good AG, Shrawat AK, Muench DG. Can less yield more? Is reducing nutrient input into the environment compatible with maintaining crop production? Trends Plant Sci. 2004;9:597-605.

5. Ding L, Wang K, Jiang G, Biswas D, Xu H, Li L, Li Y. Effects of nitrogen deficiency on photosynthetic traits of maize hybrids released in different years. Ann Bot. 2005:96:925-30.

6. Diaz C, Saliba-Colombani V, Loudet O, Belluomo P, Moreau L, DanielVedele F, Morot-Gaudry J-F, Masclaux-Daubresse C. Leaf yellowing and anthocyanin accumulation are two genetically independent strategies in response to nitrogen limitation in Arabidopsis thaliana. Plant Cell Physiol. 2006;47:74-83.

7. Bondada B, Oosterhuis D, Norman R, Baker W. Canopy photosynthesis, growth, yield, and boll $15 \mathrm{~N}$ accumulation under nitrogen stress in cotton. Crop Sci. 1996;36:127-33.

8. Chen W, Hou Z, Wu L, Liang Y, Wei C. Effects of salinity and nitrogen on cotton growth in arid environment. Plant Soil. 2010;326:61-73.

9. Hou Z, Li P, Li B, Gong J, Wang Y. Effects of fertigation scheme on N uptake and N use efficiency in cotton. Plant Soil. 2007;290:115-26.

10. Bondada BR, Oosterhuis DM. Canopy photosynthesis, specific leaf weight, and yield components of cotton under varying nitrogen supply. J Plant Nutr. 2001;24:469-77.

11. Dong H, Li W, Eneji AE, Zhang D. Nitrogen rate and plant density effects on yield and late-season leaf senescence of cotton raised on a saline field. Field Crops Res. 2012;126:137-44.

12. Mao S. Cotton Farming in China Shanghai. Shanghai: Shanghai Scientific and Technical Press; 2013.

13. S.C. Hodges, Fertilization, in: K.L.E. Edmisten (ed.) Cotton Information Publ.AG- 417, North Carolina Cooperative Extension Service, Raleigh, NC, (2002) 40-54. 
14. Godfray HCJ, Beddington JR, Crute IR, Haddad L, Lawrence D, Muir JF, Pretty J, Robinson S, Thomas SM, Toulmin C. Food security: the challenge of feeding 9 billion people. Science. 2010;327:812-8.

15. Tilman D, Balzer C, Hill J, Befort BL. Global food demand and the sustainable intensification of agriculture. Proc Natl Acad Sci USA. 2011;108:20260-4

16. Larson C. Losing arable land, China faces stark choice: adapt or go hungry. Am Assoc Adv Sci. 2013;339(6120):644.

17. Zhou L. Grain production and food security in China. In: Zhou L, editor. Reform and development of agriculture in China. Singapore: Springer; 2017. p. 141-69.

18. Zhu Z, Chen D. Nitrogen fertilizer use in China-Contributions to food production, impacts on the environment and best management strategies. Nutr Cycl Agroecosyst. 2002;63:117-27.

19. Kwong KNK, Bholah A, Volcy L, Pynee K. Nitrogen and phosphorus transport by surface runoff from a silty clay loam soil under sugarcane in the humid tropical environment of Mauritius. Agr Ecosyst Environ. 2002;91:147-57.

20. Wang X, Deng X, Pu T, Song C, Yong T, Yang F, Sun X, Liu W, Yan Y, Du J. Contribution of interspecific interactions and phosphorus application to increasing soil phosphorus availability in relay intercropping systems. Field Crops Research. 2017;204:12-22.

21. Xing G, Zhu Z. Regional nitrogen budgets for China and its major watersheds. Biogeochemistry. 2002;57:405-27.

22. Moose S, Below FE. Biotechnology approaches to improving maize nitrogen use efficiency. In: Kriz AL, Larkins A, editors. Molecular genetic approaches to maize improvement. Berlin: Springer; 2009. p. 65-77.

23. Masclaux-Daubresse C, Daniel-Vedele F, Dechorgnat J, Chardon F, Gaufichon L, Suzuki A. Nitrogen uptake, assimilation and remobilization in plants: challenges for sustainable and productive agriculture. Ann Bot. 2010;105:1141-57.

24. Moll R, Kamprath $\mathrm{E}$, Jackson W. Analysis and interpretation of factors which contribute to efficiency of nitrogen utilization 1. Agron J. 1982;74:562-4.

25. Brauer EK, Shelp BJ. Nitrogen use efficiency: re-consideration of the bioengineering approach. Botany. 2010;88:103-9.

26. A.G. Good, P.H. Beatty, Biotechnological approaches to improving nitrogen use efficiency in plants: alanine aminotransferase as a case study, The molecular and physiological basis of nutrient use efficiency in crops, (2011) 165-191.

27. Rochester IJ, O'Halloran J, Maas S, Sands D, Brotherton E. Monitoring nitrogen use efficiency in your region. Aust Cottongrower. 2007;28:24-7.

28. Novoa R, Loomis RS. Green plants play a unique role among living organisms through their ability to reduce carbon in photosynthesis. Plant Soil. 1981;58:177-204.

29. Vanlauwe B, Kihara J, Chivenge P, Pypers P, Coe R, Six J. Agronomic use efficiency of $\mathrm{N}$ fertilizer in maize-based systems in sub-Saharan Africa within the context of integrated soil fertility management. Plant Soil. 2011;339:35-50

30. Dilz K. Efficiency of uptake and utilization of fertilizer nitrogen by plants. In: Jenkinson DS, Smith KA, editors. Nitrogen efficiency in agricultural soils. London and New York: Elsevier; 1988. p. 1-26.

31. Rochester IJ. Assessing internal crop nitrogen use efficiency in highyielding irrigated cotton. Nutr Cycl Agroecosyst. 2011;90:147-56.

32. Luo Z, Liu H, Li W, Zhao Q, Dai J, Tian L, Dong H. Effects of reduced nitrogen rate on cotton yield and nitrogen use efficiency as mediated by application mode or plant density. Field Crops Research. 2018;218:150-7

33. Zhang F, Cui Z, Fan M, Zhang W, Chen X, Jiang R. Integrated soil-crop system management: reducing environmental risk while increasing crop productivity and improving nutrient use efficiency in China. J Environ Qual. 2011;40:1051-7.

34. Yu P, Li X, White PJ, Li C. A large and deep root system underlies high nitrogen-use efficiency in maize production. PLoS ONE. 2015:10:0126293.

35. Hajari E, Snyman SJ, Watt MP. Nitrogen use efficiency of sugarcane (Saccharum spp.) varieties under in vitro conditions with varied $\mathrm{N}$ supply, Plant Cell. Tissue and Organ Culture. 2015;122:21-9.
36. Cramer $\mathrm{M}$, Lewis $\mathrm{O}$. The influence of nitrate and ammonium nutrition on the growth of wheat (Triticum aestivum) and maize (Zea mays) plants. Ann Bot. 1993:72:359-65.

37. Robinson N, Brackin R, Vinall K, Soper F, Holst J, Gamage H, PaungfooLonhienne C, Rennenberg H, Lakshmanan P, Schmidt S. Nitrate paradigm does not hold up for sugarcane. PLOS ONE. 2011;6:e19045.

38. Witte CP. Urea metabolism in plants. Plant Sci. 2011;180:431-8.

39. Meyer J, Schumann A, Wood R, Nixon D, Van Den Berg M, Recent advances to improve nitrogen use efficiency of sugarcane in the South African sugar industry, In: Proceedings of the International Society of Sugar Cane Technologists, (2007), 238-246.

40. Cassman KG, Peng S, Olk D, Ladha J, Reichardt W, Dobermann A, Singh U. Opportunities for increased nitrogen-use efficiency from improved resource management in irrigated rice systems. Field Crops Research. 1998;56:7-39.

41. Liu L, Xu W, Tang C, Wang Z, Yang J. Effect of indigenous nitrogen supply of soil on the grain yield and fertilizer-N use efficiency in rice. Rice Sci. 2005:12:267-74.

42. Mengel K, Hütsch B, Kane Y. Nitrogen fertilizer application rates on cereal crops according to available mineral and organic soil nitrogen. Eur J Agron. 2006;24:343-8.

43. Mulvaney RL, Khan S, Ellsworth T. Need for a soil-based approach in managing nitrogen fertilizers for profitable corn production. Soil Sci Soc Am J. 2006;70:172-82

44. Cui Z, Zhang F, Chen X, Miao Y, Li J, Shi L, Xu J, Ye Y, Liu C, Yang Z. Onfarm evaluation of an in-season nitrogen management strategy based on soil Nmin test. Field Crops Res. 2008;105:48-55.

45. Takahashi DT. ${ }^{15} \mathrm{~N}$ nitrogen field studies with sugarcane. Hawaii Plant Rec. 1964;57:198-222.

46. Olson R, Murphy L, Moser H, Swallow C. Fate of tagged fertilizer Nitrogen applied to winter wheat 1. Soil Sci Soc Am J. 1979;43:973-5.

47. Wilson C, Wells B, Norman R. Seasonal uptake patterns of fertilizer nitrogen applied in split applications to rice. Soil Sci Soc Am J. 1989:53:1884-7.

48. Omay A, Rice C, Maddux L, Gordon W. Corn yield and nitrogen uptake in monoculture and in rotation with soybean. Soil Sci Soc Am J. 1998;62:1596-603.

49. Schindler F, Knighton R. Fate of fertilizer nitrogen applied to corn as estimated by the isotopic and difference methods. Soil Sci Soc Am J. 1999:63:1734-40.

50. Stevens W, Hoeft R, Mulvaney RL. Fate of nitrogen-15 in a long-term nitrogen rate study. Agron J. 2005:97:1046-53.

51. Lopez-Bellido L, Lopez-Bellido RJ, Lopez-Bellido FJ. Fertilizer nitrogen efficiency in durum wheat under rainfed Mediterranean conditions: Effect of split application. Agron J. 2006;98:55-62.

52. Dourado-Neto D, Powlson D, Bakar RA, Bacchi OOS, Basanta M, Keerthisinghe G, Ismaili M, Rahman S, Reichardt K, Safwat M. Multiseason recoveries of organic and inorganic nitrogen-15 in tropical cropping systems. Soil Sci Soc Am J. 2010;74:139-52.

53. Franco HCJ, Otto R, Faroni CE, Vitti AC, de Oliveira ECA, Trivelin PCO. Nitrogen in sugarcane derived from fertilizer under Brazilian field conditions. Field Crops Research. 2011;121:29-41.

54. Lory J, Scharf P. Yield goal versus delta yield for predicting fertilizer nitrogen need in corn. Agron J. 2003;95:994-9.

55. Franco HC, Trivelin PC, Eduardo FC, Vitti AC, Otto R. Stalk yield and technological attributes of planted cane as related to nitrogen fertilization. Scientia Agricola. 2010;67:579-90.

56. Rossetto R, Dias F, Landell M, Cantarella H, Tavares S, Vitti A, Perecin D. $\mathrm{N}$ and $\mathrm{K}$ fertilisation of sugarcane ratoons harvested without burning Proceeding of the International Society of Sugar Cane Technologists. 2010;27:1-8.

57. Meier EA, Thorburn PJ, Wegener MK, Basford KE. The availability of nitrogen from sugarcane trash on contrasting soils in the wet tropics of North Queensland. Nutr Cycl Agroecosyst. 2006:75:101-14.

58. Thorburn PJ, Dart IK, Biggs IM, Baillie CP, Smith MA, Keating BA. The fate of nitrogen applied to sugarcane by trickle irrigation. Irrig Sci. 2003;22:201-9.

59. Leghari SJ, Wahocho NA, Laghari GM, Hafeez Laghari A, Mustafa Bhabhan G, Hussain Talpur K, Bhutto TA, Wahocho SA, Lashari AA. Role of nitrogen for plant growth and development: a review. Adv Environ Biol. 2016:10:209-18. 
60. Neto AP, Favarin JL, de Almeida REM, dos Santos Dias CT, Tezotto T, Alves ALG, Moraes MF. Changes of nutritional status during a phenological cycle of coffee under high nitrogen supply by fertigation. Commun Soil Sci Plant Anal. 2011;42:2414-25.

61. dos Reis AR, Favarin JL, Gallo LA, Moraes MF, Tezotto T, Lavres Junior J. Influence of nitrogen fertilization on nickel accumulation and chemical composition of coffee plants during fruit development. J Plant Nutr. 2011;34:1853-66.

62. Reis AR, Favarin JL, Gallo LA, Malavolta E, Moraes MF, Lavres J, Nitrate reductase and glutamine synthetase activity in coffee leaves during fruit development. Revista Brasileira de Ciência do Solo. 2009;33:315-24

63. Fenilli TAB, Reichardt K, Dourado-Neto D, Trivelin PCO, Favarin JL, Costa FMP, Bacchi OOS. Growth, development, and fertilizer- ${ }^{15} \mathrm{~N}$ recovery by the coffee plant. Scientia Agricola. 2007;64:541-7.

64. Mazzafera P, Gonçalves KV. Nitrogen compounds in the xylem sap of coffee. Phytochemistry. 1999;50:383-6.

65. Wray JL, Fido RJ. Nitrate reductase and nitrite reductase. In: Dey PM, Harborne JB, editors. Methods in plant biochemistry. Waltham: Academic Press; 1990

66. Franco AL, Cherubin MR, Pavinato PS, Cerri CE, Six J, Davies CA, Cerri CC. Soil carbon, nitrogen and phosphorus changes under sugarcane expansion in Brazil. Sci Total Environ. 2015;515:30-8.

67. Ferreira DA, Franco HC, Otto R, Vitti AC, Fortes C, Faroni CE, Garside AL, Trivelin PC. Contribution of $N$ from green harvest residues for sugarcane nutrition in B razil. GCB Bioenergy. 2016;8:859-66.

68. Muchow R, Robertson M. Relating crop nitrogen uptake to sugarcane yield. Proceeding of Australian Society of Sugar Cane Technologists. 1994:16:122-30.

69. Granstedt RC, Huffaker RC. Identification of the leaf vacuole as a major nitrate storage pool. Plant Physiol. 1982;70:410-3.

70. Burns IG, Walker RL, Moorby J. How do nutrients drive growth? Plant Soil. 1997:196:321-5

71. Crawford NM, Glass AD. Molecular and physiological aspects of nitrate uptake in plants. Trends Plant Sci. 1998:3:389-95.

72. Duncan EG, Sulivan CA, Roper MM, Biggs JS, Peoples MB. Influence of co-application of nitrogen with phosphorus, potassium and sulphur on the apparent efficiency of nitrogen fertiliser use, grain yield and protein content of wheat: review. Field Crops Research. 2018;226:56-65.

73. Groot CC, Marcelis LFM, van Den Boogard R, Kaiser WN, Lambers H. Interaction of nitrogen and phosphorus nutrition in determining growth. Plant Soil. 2003;248:257-68.

74. Chen H, Zhang W, Gurmesa GA, Zhu X, Li D, Mo J. Phosphorus addition affects soil nitrogen dynamics in a nitrogen-saturated and two nitrogen-limited forests. Eur J Soil Sci. 2017;68:472-9.

75. Yokoyama D, Imai N, Kitayama K. Effects of nitrogen and phosphorus fertilization on the activities of four different classes of fine-root and soil phosphatases in Bornean tropical rain forests. Plant Soil. 2017:416:463-76

76. Alzubaidi A, Aljanabi AS, Al-Rawi A. Interaction between nitrogen and phosphorus fertilizers and soil salinity and its effect on growth and ionic composition of corn (Zea mays L.). In: El Bassam N, Dambroth M, Loughman BC, editors. Genetic aspects of plant mineral nutrition developments in plant and soil sciences. Dordrecht: Springer; 2018. p. 42

77. Kuzyakov Y, Xu X. Competition between roots and microorganisms for nitrogen: mechanisms and ecological relevance. New Phytol. 2013;198:656-69

78. Schimel JP, Bennett J. Nitrogen mineralization: challenges of a changing paradigm. Ecology. 2004;85:591-602.

79. Vitousek PM, Howarth RW. Nitrogen limitation on land and in the sea: how can it occur? Biogeochemistry. 1991;13:87-115.

80. Vitousek PM, Sanford RL Jr. Nutrient cycling in moist tropical forest. Annu Rev Ecol Syst. 1986;17:137-67.

81. Xu X, Thornton PE, Post WM. A global analysis of soil microbial biomass carbon, nitrogen and phosphorus in terrestrial ecosystems. Glob Ecol Biogeogr. 2013;22:737-49.

82. Galloway JN, Townsend AR, Erisman JW, Bekunda M, Cai Z, Freney $J R$, Martinelli LA, Seitzinger SP, Sutton MA. Transformation of the nitrogen cycle: recent trends, questions, and potential solutions. Science. 2008;320:889-92.

83. Tilman D, Fargione J, Wolff B, Dantonio C, Dobson A, Howarth R, Schindler D, Schlesinger WH, Simberloff D, Swackhamer D. Forecasting agriculturally driven global environmental change. Science. 2001;292:281-4.

84. Vitousek PM, Naylor R, Crews T, David MB, Drinkwater L, Holland E, Johnes P, Katzenberger J, Martinelli L, Matson P. Nutrient imbalances in agricultural development. Science. 2009:324:1519-20.

85. Liu J, You L, Amini M, Obersteiner M, Herrero M, Zehnder AJ, Yang $\mathrm{H}$. A high-resolution assessment on global nitrogen flows in cropland, Proc Natl Acad Sci USA. 2010;107:8035-40.

86. Guo JH, Liu XJ, Zhang Y, Shen J, Han W, Zhang W, Christie P, Goulding K, Vitousek P, Zhang F. Significant acidification in major Chinese croplands. Science. 2010;327:1008-10.

87. Chen X-P, Cui Z-L, Vitousek PM, Cassman KG, Matson PA, Bai J-S, Meng Q-F, Hou P, Yue S-C, Römheld V. Integrated soil-crop system management for food security. Proc Natl Acad Sci USA. 2011;108:6399-404.

88. Zhao X, Zhou Y, Min J, Wang S, Shi W, Xing G. Nitrogen runoff dominates water nitrogen pollution from rice-wheat rotation in the Taihu Lake region of China. Agr Ecosyst Environ. 2012;156:1-11.

89. Zhang WF, Dou ZX, He P, Ju XT, Powlson D, Chadwick D, Norse D, Lu YL, Zhang Y, Wu L. New technologies reduce greenhouse gas emissions from nitrogenous fertilizer in China. Proc Natl Acad Sci USA. 2013;110:8375-80.

90. Socolow RH. Nitrogen management and the future of food: lessons from the management of energy and carbon. Proc Natl Acad Sci. 1999;96:6001-8.

91. Zhang Q. Strategies for developing green super rice. Proc Natl Acad Sci USA. 2007;104:16402-9.

92. Peoples M, Herridge D, Ladha J. Biological nitrogen fixation: an efficient source of nitrogen for sustainable agricultural production. In: Ladha JK, Peoples MB, editors. Management of biological nitrogen fixation for the development of more productive and sustainable agricultural systems. Berlin: Springer; 1995. p. 3-28.

93. Matson PA, Naylor R, Ortiz-Monasterio I. Integration of environmental, agronomic, and economic aspects of fertilizer management. Science. 1998:280:112-5.

94. Panek J, Matson P, Ortiz-Monasterio I, Brooks P. Distinguishing nitrification and denitrification sources of $\mathrm{N} 2 \mathrm{O}$ in a Mexican wheat system using ${ }^{15} \mathrm{~N}$. Ecol Appl. 2000;10:506-14.

95. Matějková Š, Kumhálová J, Lipavský J. Evaluation of crop yield under different nitrogen doses of mineral fertilization. Plant, Soil and Environment. 2010;56:163-7.

96. Mariano E, Leite JM, Megda MX, Torres-Dorante L, Trivelin PC. Influence of nitrogen form supply on soil mineral nitrogen dynamics, nitrogen uptake, and productivity of sugarcane. Agron J. 2015;107:641-50.

97. Otto R, Mulvaney RL, Khan S, Trivelin P. Quantifying soil nitrogen mineralization to improve fertilizer nitrogen management of sugarcane. Biol Fertil Soils. 2013;49:893-904.

98. Cantarella H, Trivelin PCO, Contin TLM, Dias FLF, Rossetto R, Marcelino R, Coimbra RB, Quaggio JA. Ammonia volatilisation from urease inhibitortreated urea applied to sugarcane trash blankets. Scientia Agricola. 2008;65:397-401.

99. Ghiberto P, Libardi P, Brito A, Trivelin PCO. Leaching of nutrients from a sugarcane crop growing on an Ultisol in Brazil. Agric Water Manag. 2009:96:1443-8.

100. Ghiberto P, Libardi $P$, Trivelin P. Nutrient leaching in an Ultisol cultivated with sugarcane. Agric Water Manag. 2015;148:141-9.

101. Oliveira JCM, Reichardt K, Bacchi OO, Timm LC, Dourado-Neto D, Trivelin PCO, Tominaga TT, Navarro RC, Piccolo MC, Cássaro FAM. Nitrogen dynamics in a soil-sugar cane system. Scientia Agricola. 2000:57:467-72.

102. Signor $\mathrm{D}$, Cerri CEP, Conant R. $\mathrm{N}_{2} \mathrm{O}$ emissions due to nitrogen fertilizer applications in two regions of sugarcane cultivation in Brazil. Environ Res Lett. 2013;8:015013.

103. Carmo JB, Filoso S, Zotelli LC, de Sousa Neto ER, Pitombo LM, DuarteNeto PJ, Vargas VP, Andrade CA, Gava GJ, Rossetto R. Infield greenhouse gas emissions from sugarcane soils in Brazil: effects from synthetic and organic fertilizer application and crop trash accumulation. Gcb Bioenergy. 2013:5:267-80. 
104. Fortes C, Trivelin PCO, Vitti AC. Long-term decomposition of sugarcane harvest residues in Sao Paulo state, Brazil. Biomass Bioenergy. 2012:42:189-98

105. Vieira-Megda MX, Mariano E, Leite JM, Franco HCJ, Vitti AC, Megda MM, Khan SA, Mulvaney RL, Trivelin PCO. Contribution of fertilizer nitrogen to the total nitrogen extracted by sugarcane under Brazilian field conditions. Nutr Cycl Agroecosyst. 2015;101:241-57.

106. Otto R, Castro S, Mariano E, Castro S, Franco H, Trivelin PCO. Nitrogen use efficiency for sugarcane-biofuel production: what is next? Bioenergy Res. 2016;9:1272-89.

107. Khan S, Mulvaney RL, Ellsworth T, Boast C. The myth of nitrogen fertilization for soil carbon sequestration. J Environ Qual. 2007;36:1821-32.

108. Ladha JK, Reddy CK, Padre AT, Van Kessel C. Role of nitrogen fertilization in sustaining organic matter in cultivated soils. J Environ Qual. 2011;40:1756-66.

109. Mulvaney RL, Khan S, Ellsworth T. Synthetic nitrogen fertilizers deplete soil nitrogen: a global dilemma for sustainable cereal production. J Environ Qual. 2009:38:2295-314.

110. Darrouzet-Nardi A, Weintraub MN. Evidence for spatially inaccessible labile $\mathrm{N}$ from a comparison of soil core extractions and soil pore water lysimetry. Soil Biol Biochem. 2014;73:22-32.

111. Inselsbacher E. Recovery of individual soil nitrogen forms after sieving and extraction. Soil Biol Biochem. 2014;71:76-86.

112. Inselsbacher E, Oyewole OA, Näsholm T. Early season dynamics of soil nitrogen fluxes in fertilized and unfertilized boreal forests. Soil Biol Biochem. 2014;74:167-76.

113. Sommer SG, Schjoerring JK, Denmead O. Ammonia emission from mineral fertilizers and fertilized crops. Adv Agron. 2004;82:82008.

114. Haenel HD, Rosemann C, Dammgen U, Freibauer A, Doring U, Wulf S, Eurich-Menden B, Dohler H, Schreiner C, Osterburg B. Calculations of gaseous and particulate emissions from German agriculture 19902014: Report on methods and data (RMD) submission 2016. Johann Heinrich von Thuenen-Institut, Braunschweig, Report. 2016;39:412.

115. Skocaj DM, Everingham YL, Schroeder BL. Nitrogen management guidelines for sugarcane production in Australia: can these be modified for wet tropical conditions using seasonal climate forecasting? Springer Sci Rev. 2013;1:51-71.

116. Ghiberto PJ, Libardi PL, Brito AS, Trivelin PCO. Nitrogen fertilizer leaching in an Oxisol cultivated with sugarcane. Scientia Agricola. 2011;68:86-93.

117. Duan W, Wang Q, Zhang H, Xie B, Li A, Hou F, Dong S, Wang B, Qin Z, Zhang L. Differences between nitrogen-tolerant and nitrogen-susceptible sweetpotato cultivars in photosynthate distribution and transport under different nitrogen conditions. PLoS ONE. 2018;13:e0194570.

118. Wu C, Liu Q, Kong F, Li H, Shi Y. Effects of nitrogen application rates on root yield and nitrogen utilization in different purple sweetpotato varieties. Aata Agronomica Sinica. 2016;42:113-22.

119. Walker $D$, Woodson W. Nitrogen rate and cultivar effects on nitrogen and nitrate concentration of sweet potato leaf tissue. Commun Soil Sci Plant Anal. 1987;18:529-41.

120. W. L.A., Eco-physiology of tropical crops, in: KT Alvim PDT (ed.) Root crops, Academic Press, New York, 1977, p. 187-236.

121. Xue L, Li G, Qin $X$, Yang $L$, Zhang $H$. Topdressing nitrogen recommendation for early rice with an active sensor in South China. Precis Agric. 2014;15:95-110.

122. Liu C, Wang K, Meng S, Zheng X, Zhou Z, Han S, Chen D, Yang Z. Effects of irrigation, fertilization and crop straw management on nitrous oxide and nitric oxide emissions from a wheat-maize rotation field in northern China. Agr Ecosyst Environ. 2011;140:226-33.

123. Yan G, Zheng X, Cui F, Yao Z, Zhou Z, Deng J, Xu Y. Two-year simultaneous records of $\mathrm{N} 2 \mathrm{O}$ and $\mathrm{NO}$ fluxes from a farmed cropland in the northern China plain with a reduced nitrogen addition rate by one-third. Agr Ecosyst Environ. 2013;178:39-50.

124. Drinkwater LE, Wagoner P, Sarrantonio M. Legume-based cropping systems have reduced carbon and nitrogen losses. Nature. 1998;396:262.

125. Salvagiotti F, Cassman KG, Specht JE, Walters DT, Weiss A, Dobermann A. Nitrogen uptake, fixation and response to fertilizer $N$ in soybeans: a review. Field Crops Res. 2008;108:1-13.

126. Graham M, Haynes R, Meyer J. Changes in soil chemistry and aggregate stability induced by fertilizer applications, burning and trash retention on a long-term sugarcane experiment in South Africa. Eur J Soil Sci. 2002;53:589-98.
127. de Resende AS, Xavier RP, de Oliveira OC, Urquiaga S, Alves BJ, Boddey RM. Long-term effects of pre-harvest burning and nitrogen and vinasse applications on yield of sugar cane and soil carbon and nitrogen stocks on a plantation in Pernambuco, NE Brazil. Plant and Soil. 2006;281:339-51.

128. Ju X-T, Xing G-X, Chen X-P, Zhang S-L, Zhang L-J, Liu X-J, Cui Z-L, Yin $B$, Christie P, Zhu Z-L. Reducing environmental risk by improving N management in intensive Chinese agricultural systems. Proc Natl Acad Sci USA. 2009;106:3041-6.

129. Zhang Y, Li S, Fu W, Wen H. Effects of nitrogen application on yield, photosynthetic characteristics and water use efficiency of hybrid millet. J Plant Nutr Fertil. 2014;20:1119-26.

130. Pei-ling LI, Fu-cang ZH. Coupling effects of partitioning alternative drip irrigation with plastic mulch and nitrogen fertilization on cotton dry matter accumulation and nitrogen use. Chin J Appl Ecol. 2013;24:416-22.

131. Schumann A. Prospects for improving nitrogen fertiliser use efficiency with a new soil test and ammonia volatilisation model. Pro Ann Congr $S$ Afr Sugar Technol Assoc. 2000;73:70-8.

132. Weigel A, Miles N, Nyandeni B, Naidoo G, Wettergreen T. Ammonia volatilisation losses from nitrogen fertilisers: laboratory studies. Proc Ann Congr S Afr Sugar Technol Assoc. 2014;87:353-7.

133. Weigel A, Naidoo G, Eustice T. Atmospheric nitrogen deposition: what does it tell you. Proc Ann Congr S Afr Sugar Technol Assoc. 2009;82:639-41.

134. Srivastava S. Sugarcane. In: Wichmann W, editor. IAF world fertilizer use manual. Paris: International Fertilizer Industry Association; 1992. p. 257-66.

135. A.A.A.F. Dametie, Determination of optimum nitrogen rate for sugarcane at Wonji-Shoa sugarcane plantation, in: 1st Ethiopian Sugar Industries Biennial Conference, Adama, Ethiopia, (2009) 23-24.

136. van DILLEWIJN C. Botany of sugarcane, Botany of sugarcane. Waltham: The Chronica Botanica Co. Book Department; 1952

137. Rakkiyappan P, Thangavelu S, Bhagyalakshmi K, Radhamani R. Uptake of nitrogen, phosphorus and potassium by some promising mid late maturing sugarcane clones. Sugar Tech. 2007:9:23-7.

138. Amaral LR, Molin JP, Portz G, Finazzi FB, Cortinove L. Comparison of crop canopy reflectance sensors used to identify sugarcane biomass and nitrogen status. Precis Agric. 2015;16:15-28.

139. Rochester I, Ceeney S, Maas S, Gordon R, Hanna L, Hill J. Monitoring nitrogen use efficiency in cotton crops. Austral Cottongrow. 2009;30:42.

140. Dong H, Kong X, Li W, Tang W, Zhang D. Effects of plant density and nitrogen and potassium fertilization on cotton yield and uptake of major nutrients in two fields with varying fertility. Field Crops Res. 2010;119:106-13.

141. Boquet DJ. Cotton in ultra-narrow row spacing. Agron J. 2005;97:279-87.

142. Clawson EL, Cothren JT, Blouin DC, Satterwhite JL. Timing of maturity in ultra-narrow and conventional row cotton as affected by nitrogen fertilizer rate. Agron J. 2008;100:421-31.

143. Janat M. Response of cotton to irrigation methods and nitrogen fertilization: yield components, water-use efficiency, nitrogen uptake, and recovery. Commun Soil Sci Plant Anal. 2008:39:2282-302.

144. Kumbhar A, Buriro U, Junejo S, Oad F, Jamro G, Kumbhar B, Kumbhar S. Impact of different nitrogen levels on cotton growth, yield and N-uptake planted in legume rotation. Pak J Bot. 2008;40:767-78.

145. CONAB, Monitoring of the Brazilian coffee production of 2009, in, Companhia Nacional de Abastecimento, Brasilia, (2010).

146. Neto AP, Favarin JL, dos Reis AR, Tezotto T, de Almeida REM, Junior $J L$, Gallo LA. Nitrogen metabolism in coffee plants in response to nitrogen supply by fertigation. Theor Exp Plant Physiol. 2015;27:41-50.

147. Bruulsema T, Lemunyon J, Herz B. Know your fertilizer rights. Crops Soils. 2009:42:13-8.

148. Ancev T, Whelan B, McBratney A, Stafford J. Evaluating the benefits from precision agriculture: the economics of meeting traceability requirements and environmental targets. Precis Agric. 2005;5:985-92.

149. U. Schmidhalter, F.-X. Maidl, H. Heuwinkel, M. Demmel, H. Auernhammer, P. Noack, M. Rothmund, Precision farming-adaptation of land use management to small scale heterogeneity, in: Perspectives for Agroecosystem Management, Elsevier, (2008) 121-199. 
150. Reetz FR, Fixen PE. Economic analysis of site-specific nutrient management systems. In: Robert PC, Rust RH, Larson WE, editors. Proceeding of site-specific management for agricultural systems: second international conference, March 27-30, 1994. Minnesota: Minneapolis; 1995. p. 734-52.

151. Mistele B, Schmidhalter U. Estimating the nitrogen nutrition index using spectral canopy reflectance measurements. Eur J Agron. 2008;29:184-90.

152. Schächtl J, Huber G, Maidl F-X, Sticksel E, Schulz J, Haschberger P. Laserinduced chlorophyll fluorescence measurements for detecting the nitrogen status of wheat (Triticum aestivum L.) canopies. Precis Agric. 2005:6:143-56.

153. Bredemeier C, Schmidhalter U. Laser-induced chlorophyll fluorescence sensing to determine biomass and nitrogen uptake of winter wheat under controlled environment and field conditions. Precis Agric. 2005;6:273-80.

154. Chappelle EW, Wood FM, McMurtrey JE, Newcomb WW. Laser-induced fluorescence of green plants. 1: A technique for the remote detection of plant stress and species differentiation. Appl Opt. 1984;23:134-8.

155. Lichtenthaler HK, Rinderle U. The role of chlorophyll fluorescence in the detection of stress conditions in plants. CRC Crit Rev Anal Chem. 1988;19:S29-85.

156. Chappelle EW, McMurtrey JE, Wood FM, Newcomb WW. Laser-induced fluorescence of green plants. 2: LIF caused by nutrient deficiencies in corn. Appl Opt. 1984;23:139-42.

157. Raun W, Solie J, Taylor R, Arnall D, Mack C, Edmonds D. Ramp calibration strip technology for determining midseason nitrogen rates in corn and wheat. Agron J. 2008;100:1088-93.

158. Shaver T, Khosla R, Westfall D. Evaluation of two crop canopy sensors for nitrogen variability determination in irrigated maize. Precis Agric. 2011:12:892-904.

159. Bausch WC, Brodahl MK. Strategies to evaluate goodness of reference strips for in-season, field scale, irrigated corn nitrogen sufficiency. Precis Agric. 2012;13:104-22.

160. P. Magalhães, G. Sanches, H. Franco, C. Driemeier, O. Kölln, O. Braunbeck, Precision agriculture in sugarcane production: A key tool to understand its variability, in: 12th International Conference on Precision Agriculture, Sacramento, CA, 2014, pp. 20-23.

161. Yong TW, Ping C, Qian D, Qing D, Feng Y, Wang XC, Liu WG, Yang WY. Optimized nitrogen application methods to improve nitrogen use efficiency and nodule nitrogen fixation in a maize-soybean relay intercropping system. J Integr Agric. 2018;17:664-76.

162. Kaupa P, Rao BR. Nitrogen mineralization and efficiency from coapplied animal manures and mineral fertilizer in sweetpotato under humid tropical conditions. Field Crops Res. 2014;168:48-56.

163. Raun WR, Solie JB, Johnson GV, Stone ML, Mullen RW, Freeman KW, Thomason WE, Lukina EV. Improving nitrogen use efficiency in cereal grain production with optical sensing and variable rate application. Agron J. 2002;94:815-20.

164. Zillmann E, Graeff S, Link J, Batchelor WD, Claupein W. Assessment of cereal nitrogen requirements derived by optical on-the-go sensors on heterogeneous soils. Agron J. 2006;98:682-90.

165. G. Portz, L. Amaral, J.P. Molin, J. Jasper, Optimum sugarcane growth stage for canopy reflectance sensor to predict biomass and nitrogen uptake, in: Internation Conference on Precision Agriculture, (2012).

166. Rios do Amaral L, Molin JP. The effectiveness of three vegetation indices obtained from a canopy sensor in identifying sugarcane response to nitrogen. Agron J. 2014;106:273-80.

167. E. Oliveira, Sugarcane nutritional balance related to nitrogen fertilization, Portuguese with English abstract.) Ph. D. Dissertation, University of São Paulo, Piracicaba, SP, Brazil. 2011. http://www.teses.usp.br/teses/ disponiveis/11/11140/tde-20042011-094249/en.php. Accessed 30 Apr 2015

168. Boddey RM, Urquiaga S, Alves BJ, Reis V. Endophytic nitrogen fixation in sugarcane: present knowledge and future applications. Plant Soil. 2003:252:139-49

169. Gava GJC, Trivelin PCO, Vitti AC, Oliveira MW. Urea and sugarcane straw nitrogen balance in a soil-sugarcane crop system. Pesquisa Agropecuária Brasileira. 2005:40:689-95.

170. Schultz N, Morais RF, Silva JA, Baptista RB, Oliveira RP, Leite JM, Pereira W, Júnior C, de Barros J, Alves BJR. Agronomic evaluation of varieties of sugar cane inoculated with diazotrophic bacteria and fertilized with nitrogen. Pesquisa Agropecuária Brasileira. 2012;47:261-8.

171. Li Y, Wang F, Sun J, Liu H, Yang J, Xian F, Su H. Coupling effect of water and nitrogen on mechanically harvested cotton with drip irrigation under plastic film in arid area of western Inner Mongolia, China. J Appl Ecol. 2016;27:845-54.

172. Neelam P. Rajput T. Simulation and modeling of water movement in potato (Solanum tuberosum) under subsurface drip system. Indian J Agric Sci. 2011;81:25-32.

173. Ayyadurai P, Manickasundaram P. Growth, nutrient uptake and seed cotton yield as influenced by foliar nutrition and drip fertigation in cotton hybrid. International Journal of Agricultural Sciences. 2014;10:276-9.

174. Dai J, Dong H. Intensive cotton farming technologies in China: achievements, challenges and countermeasures. Field Crops Res. 2014;155:99-110.

175. B. Bar-Yosef, Advances in fertigation. In: Advances in Agronomy, Elsevier, (1999) 1-77.

176. Yan KF, Peng FT, Qi YJ, Dang ZQ, Zhang JH, Jiang XM. Effects of different irrigation and fertilizer methods on space variation of nitrate nitrogen and nitrogen fertilization absorption and utilization of plants. Water Saving Irrigation. 2015;9:33-8.

177. Ma HY, Shi WQ, Liu YA, Xian AM, Wang JG. Effect of different irrigation and fertilization methods on yield and water and fertilizer use efficiency of pineapple. Chin J Trop Crops. 2016;37:1882-8.

178. Jayakumar M, Surendran U, Manickasundaram P. Drip fertigation effects on yield, nutrient uptake and soil fertility of Bt cotton in semi arid tropics. Int J Plant Prod. 2014;8:375-90

179. Li J, Zhang J, Rao M. Wetting patterns and nitrogen distributions as affected by fertigation strategies from a surface point source. Agric Water Manag. 2004;67:89-104.

180. Li Z, Wang H, Zhang F, Wu L, Wang Z, Zhou J. Effects of water-fertilizer coupling on field cotton growth and yield under fertigation in Xinjiang. J Drain Irrig Mach Eng. 2015;33:1069-77.

181. Anas M, Jabbar A, Sarwar MA, Ullah R, Abuzar MK, ljaz A, Latif S. Intercropping sunflower with mungbean for improved productivity and net economic return under irrigated conditions. Pak J Agric Res. 2017:30:338.

182. Wang SL, Du HY, Qi H, Zhang Q, Lin YZ, Wang ZZ, Li ZF, Feng GY. Effects of density, fertilizer and chemical control on cotton development traits and yield. J Hebei Agric Sci. 2012;16:22-5.

183. Singh I, Srivastava AK, Chandna P, Gupta RK. Crop sensors for efficient nitrogen management in sugarcane: potential and constraints. Sugar Tech. 2006;8:299-302.

184. Scharf PC, Lory JA. Calibrating reflectance measurements to predict optimal sidedress nitrogen rate for corn. Agron J. 2009;101:615-25.

185. Holland K, Schepers J. Derivation of a variable rate nitrogen application model for in-season fertilization of corn. Agron J. 2010;102:1415-24.

186. Kitchen NR, Sudduth KA, Drummond ST, Scharf PC, Palm HL, Roberts DF, Vories ED. Ground-based canopy reflectance sensing for variablerate nitrogen corn fertilization. Agron J. 2010;102:71-84.

187. Schmidt J, Beegle D, Zhu Q, Sripada R. Improving in-season nitrogen recommendations for maize using an active sensor. Field crops Res. 2011:120.94-101.

188. Solie JB, Monroe AD, Raun WR, Stone ML. Generalized algorithm for variable-rate nitrogen application in cereal grains. Agron J. 2012;104:378-87.

189. G. Vellidis, H. Savelle, R. Ritchie, G. Harris, R. Hill, H. Henry, NDVI response of cotton to nitrogen application rates in Georgia, USA, In: Precision Agriculture 2011-Proceedings of the 8th European Conference on Precision Agriculture (8ECPA), Praque, Czech Republic, (2011) 358-368.

190. Mullen RW, Freeman KW, Raun WR, Johnson GV, Stone ML, Solie JB. Identifying an in-season response index and the potential to increase wheat yield with nitrogen. Agron J. 2003;95:347-51.

191. Raun W, Solie J, Stone M, Martin K, Freeman K, Mullen R, Zhang H, Schepers J, Johnson G. Optical sensor-based algorithm for crop nitrogen fertilization. Commun Soil Sci Plant Anal. 2005;36:2759-81.

192. Schepers J, Francis D, Vigil M, Below FE. Comparison of corn leaf nitrogen concentration and chlorophyll meter readings. Commun Soil Sci Plant Anal. 1992;23:2173-87. 
193. Wu B, Fullen MA, Li J, An T, Fan Z, Zhou F, Zi S, Yang Y, Xue G, Liu Z. Integrated response of intercropped maize and potatoes to heterogeneous nutrients and crop neighbours. Plant Soil. 2014;374:185-96.

194. Oljaca S, Cvetkovic R, Kovacevic D, Vasic G, Momirovic N. Effect of plant arrangement pattern and irrigation on efficiency of maize (Zea mays) and bean (Phaseolus vulgaris) intercropping system. J Agric Sci. 2000;135:261-70.

195. Li L, Zhang F, Li X, Christie P, Sun J, Yang S, Tang C. Interspecific facilitation of nutrient uptake by intercropped maize and faba bean. Nutr Cycl Agroecosyst. 2003;65:61-71.

196. Li L, Sun J, Zhang F, Li X, Rengel Z, Yang S. Wheat/maize or wheat/ soybean strip intercropping: II. Recovery or compensation of maize and soybean after wheat harvesting. Field Crops Research. 2001;71:173-81.

197. Hochman Z, Carberry P, Robertson M, Gaydon D, Bell L, Mclntosh P. Prospects for ecological intensification of Australian agriculture. Eur J Agron. 2013;44:109-23.

198. Liu X, Rahman T, Yang F, Song C, Yong T, Liu J, Zhang C, Yang W. PAR interception and utilization in different maize and soybean intercropping patterns. PLoS ONE. 2017;12:e0169218.

199. Yang F, Liao D, Wu X, Gao R, Fan Y, Raza MA, Wang X, Yong T, Liu W, Liu J. Effect of aboveground and belowground interactions on the intercrop yields in maize-soybean relay intercropping systems. Field Crops Res. 2017;203:16-23.

200. Gao Y, Duan A, Qiu X, Sun J, Zhang J, Liu H, Wang H. Distribution and use efficiency of photosynthetically active radiation in strip intercropping of maize and soybean. Agron J. 2010;102:1149-57.

201. Xiang D, Yong T, Yang W, Gong W, Cui L, Lei T. Effect of phosphorus and potassium nutrition on growth and yield of soybean in relay strip intercropping system. Sci Res Essays. 2012;7:342-51.

202. Yang F, Huang S, Gao R, Liu W, Yong T, Wang X, Wu X, Yang W. Growth of soybean seedlings in relay strip intercropping systems in relation to light quantity and red: far-red ratio. Field Crops Res. 2014;155:245-53.

203. Yong T, Liu X, Yang F, Song C, Wang X, Liu W, Su B, Zhou L, Yang W. Characteristics of nitrogen uptake, use and transfer in a wheat-maizesoybean relay intercropping system. Plant Prod Sci. 2015;18:388-97.

204. Yan Y, Gong W, Yang W, Wan Y, Chen X, Chen Z, Wang L. Seed treatment with uniconazole powder improves soybean seedling growth under shading by corn in relay strip intercropping system. Plant Prod Sci. 2010;13:367-74

205. Gan Y, Stulen I, Posthumus F, van Keulen H, Kuiper P. Effects of N management on growth, $\mathrm{N} 2$ fixation and yield of soybean. Nutr Cycl Agroecosyst. 2002;62:163-74.

206. Thilakarathna MS, McElroy MS, Chapagain T, Papadopoulos YA, Raizada MN. Belowground nitrogen transfer from legumes to non-legumes under managed herbaceous cropping systems. A review. Agron Sustain Dev. 2016;36:58

207. Stern W. Nitrogen fixation and transfer in intercrop systems. Field Crops Res. 1993;34:335-56

208. Meyer C, Stitt M. Nitrate reductase and signalling. In: Lea PJ, MorotGaudry J-F, editors. Plant Nitrogen. New York: Springer; 2001. p. 37-59.

209. Frink CR, Waggoner PE, Ausubel JH. Nitrogen fertilizer: retrospect and prospect. Proc Natl Acad Sci USA. 1999;96:1 175-80.

210. Lea PJ, Morot-Gaudry JF. Plant Nitrogen. Berlin: Springer; 2001. p. 11.

211. Lea PJ, Miflin BJ. Transport and metabolism of asparagines and other nitrogen compounds within the plant. In: Miflin BJ, editor. The biochemistry of plants: amino acids and derivatives. New York: Academic Press; 1980. p. 569-607.

212. Crawford NM, Arst HN. The molecular genetics of nitrate assimilation in fungi and plants. Annu Rev Genet. 1993;27:115-46.

213. Lea PJ. Nitrogen metabolism. In: Lea PJ, Leegood RC, editors. Plant biochemistry and molecular biology. New York: Wiley; 1993. p. 155-80.

214. Peoples MB, Gifford RM. Long-distance transport of carbon and nitrogen from sources to sinks in higher plants. In: Dennis DT, Turpin $\mathrm{DH}$, editors. Plant physiology, biochemistry and molecular biology. New York: Wiley; 1993. p. 434-47.

215. Dubois F, Terce-Laforgue T, Gonzalez-Moro BM, Estavillo MB, Sangwan R, Gallais A, Hirel B. Glutamate dehydrogenase in plants: is there a new story for an old enzyme? Plant Physiol Biochem. 2003;41:565-76.

216. Hirel B, Andrieu B, Valadier MH, Renard S, Quillere I, Chelle M, Pommel B, Fournier C, Drouet JL. Physiology of maize II: identification of physiological markers representative of the nitrogen status of maize (Zea mays) leaves during grain filling. Physiol Plant. 2005;124:178-88.

217. Oliveira I, Brears T, Knight T, Clark A, Coruzzi G. Overexpression of cytosolic glutamine synthetase Relation to nitrogen, light, and photorespiration. Plant Physiol. 2002;129:1170-80.

218. Yamaya T, Obara M, Nakajima H, Sasaki S, Hayakawa T, Sato T. Genetic manipulation 979 and quantitative-trait loci mapping for nitrogen recycling in rice. J Exp Bot. 2002;53:917-25.

219. Miflin BJ, Habash DZ. The role of glutamine synthetase and glutamate dehydrogenase in nitrogen assimilation and possibilities for improvement in the nitrogen utilization of crops. J Exp Bot. 2002;53:979-87.

220. Aubert S, Bligny R, Douce R, Gout E, Ratcliffe RG, Roberts JKM. Contribution of glutamate dehydrogenase to mitochondrial glutamate metabolism studied by ${ }^{13} \mathrm{C}$ and ${ }^{31} \mathrm{P}$ nuclear magnetic resonance. J Exp Bot. 2001;52:37-45.

221. Ward M, Grimes H, Huffaker R. Latent nitrate reductase activity is associated with the plasma membrane of corn roots. Planta. 1989;177:470-5.

222. Unno H, Uchida T, Sugawara H, Kurisu G, Sugiyama T, Yamaya T, et al. Atomic structure of plant glutamine synthetase: a key enzyme for plant productivity. J Biol Chem. 2006:281:29287-96.

223. Keys A, Bird I, Cornelius M, Lea P, Wallsgrove R, Miflin B. Photorespiratory nitrogen cycle. Nature. 1978;275:741-3.

224. Bernard SM, Habash DZ. The importance of cytosolic glutamine synthetase in nitrogen assimilation and recycling. New Phytol. 2009;182:608-20.

225. Vanoni M, Dossena L, van den Heuvel R, Curti B. Structure-function studies on the complex iron-sulfur flavoprotein glutamate synthase: the key enzyme of ammonia assimilation. Photosynth Res. 2005;83:219-38.

226. Masclaux-Daubresse C, Reisdorf-Cren M, Pageau K, Lelandais M Grandjean O, Kronenberger J, Valadier MH, Feraud M, Jouglet T, Suzuki A. Glutamine synthetase-glutamate synthase pathway and glutamate dehydrogenase play distinct roles in the sink-source nitrogen cycle in tobacco. Plant Physiol. 2006;140:444-56.

227. Rochat C, Boutin JP. Metabolism of phloem-borne amino acids in maternal tissues of fruit of nodulated or nitrate-fed pea plants (Pisum sativum L.). J Exp Bot. 1991:42:207-14.

228. Lam HM, Wong P, Chan HK, Yam KM, Chen L, Chow CM, Coruzzi GM. Overexpression of the ASN1 gene enhances nitrogen status in seeds of Arabidopsis. Plant Physiol. 2003;132:926-35.

229. Potel F, Valadier MH, Ferrario-Mery S, Grandjean O, Morin H, Gaufichon L, Boutet-Mercey S, Lothier J, Rothstein SJ, Hirose N, Suzuki A. Assimilation of excess ammonium into amino acids and nitrogen translocation in Arabidopsis thaliana - roles of glutamate synthases and carbamoylphosphate synthetase in leaves. FEBS J. 2009;276:4061-76.

230. Skopelitis D, Paranychianakis N, Paschalidis K, Pliakonis E, Delis I, Yakoumakis D, Kouvarakis A, Papadakis A, Stephanou E, Roubelakis-Anfelakis $\mathrm{K}$. Abiotic stress generates ROS that signal expression of anionic glutamate dehydrogenases to form glutamate for proline synthesis in tobacco and grapevine. Plant Cell. 2006;18:2767-81.

231. Garnett T, Plett D, Heuer S, Okamoto M. Genetic approaches to enhancing nitrogen-use efficiency (NUE) in cereals:challenges and future directions. Funct Plant Biolohy. 2015;42:921-94.

232. Miller AJ, Fan X, Shen Q, Smith SJ. Amino acids and nitrate as signals for the regulation of nitrogen acquisition. J Exp Bot. 2008;59:111-9.

233. Sanders A, Collier R, Trethewy A, Gould G, Sieker R, Tegeder M. AAP1 regulates import of amino acids into developing Arabidopsis embryos. Plant J. 2009:59:540-52.

234. Tan Q, Zhang L, Grant J, Cooper P, Tegeder M. Increased phloem transport of S-methylmethionine positively affects sulfur and nitrogen metabolism and seed development in pea plants. Plant Physiolol. 2010;154:1886-96.

235. Forde B. Glutamate signalling in roots. J Exp Bot. 2014;65:779-87.

236. Santiago J, Tegeder M. Connecting source with sink: the role of Arabidopsis AAP8 in phloem loading of amino acids. Plant Physiol. 2016;171:508-21.

237. Fang Z, Xia K, Yang X, Grotemeyer MS, Meier S, Rentsch D, Xu X, Zhang M. Altered expression of the PTR/NRT1 homologue OsPTR9 affects nitrogen utilization efficiency, growth and grain yield in rice. Plant Biotechnol J. 2013;11:446-58. 
238. Araus V, Vidal EA, Puelma T, Alamos S, Mieulet D, Guiderdoni E, Gutiérrez RA. Members of BTB gene family of scaffold proteins suppress nitrate uptake and nitrogen use efficiency. Plant Physiol. 2016;171:1523-32.

239. Chen J, Fan X, Qian K, Zhang Y, Song M, Liu Y, Xu G, Fan X. pOsNAR2.1:OsNAR2.1 expression enhances nitrogen uptake efficiency and grain yield in transgenic rice plants. Plant Biotechnol J. 2017. https //doi.org/10.1111/pbi.12714.

240. Y.F. Tsay, S.C. Fan, H.Y. Chen. Method for changing nitrogen utilization efficiency in plants. U.S. Patent Application (2011) 12/832, 2347.

241. Ameziane R, Bernhard K, Lightfoot D. Expression of the bacterial $g d h A$ gene encoding a NADHP glutamate dehydrogenase in tobacco affects plant growth and development. Plant Soil. 2000;22:147-57.

242. Chichkova S, Arellano J, Vance CP, Hernández G. Transgenic tobacco plants that overexpress alfalfa NADH-glutamate synthase have higher carbon and nitrogen content. J Exp Bot. 2001;52:2079-87.

243. Habash DZ, Massiah AJ, Rong HL, Wallsgrove RM, Leigh RA. The role of cytosolic glutamine synthetase in wheat. Ann Appl Biol. 2001;138:83-9.

244. Seiffert B, Zhou Z, Wallbraun M, Lohaus G, Möllers C. Expression of a bacterial asparagine synthetase gene in oilseed rape (Brassica napus) and its effect on traits related to nitrogen efficiency. Physiol Plant. 2004;121:656-65.

245. Good A, Johnson S, de Pauw M, Carroll R, Savidov N, Vidmar J, Lu Z, Taylor G, Stroeher V. Engineering nitrogen use efficiency with alanine aminotransferase. Can J Bot. 2007:85:252-62.

246. Shrawat A, Carroll R, de Pauw M, Taylor G. Good A Genetic engineering of improved nitrogen use efficiency in rice by the tissuespecific expression of alanine aminotransferase. Plant Biotechnol J. 2008;6:722-32.

247. Peña PA, Quach T, Sato S, Ge Z, Nersesian N, Changa T, Dweikat I, Soundararajan M, Clemente TE. Expression of the maize Dof1 transcription factor in wheat and sorghum. Front Plant Sci. 2017:8:434.

248. Yanagisawa S, Akiyama A, Kisaka H, Uchimiya H, Miwa T. Metabolic engineering with Dof1 transcription factor in plants: improved nitrogen assimilation and growth under low-nitrogen conditions. Proc Natl Acad Sci USA. 2004;101:7833-8.

249. Ferrario-Mery S, Besin E, Pichon O, Meyer C, Hodges M. The regulatory PII protein controls arginine biosynthesis in Arabidopsis. FEBS Lett. 2006:580:2015-20.

250. Ferrario-Mery S, Valadier M, Foyer C. Overexpression of nitrate reductase in tobacco delays drought-induced decreases in nitrate reductase activity and mRNA. Plant Physiol. 1998;117:293-302.

251. Hoshida H, Tanaka Y, Hibino T, Hayashi Y, Anaka TA, Takabe T. Enhanced tolerance to salt stress in transgenic rice that overexpresses chloroplast glutamine synthetase. Plant Mol Biol. 2000;43:103-11.

252. Migge A, Carrayol E, Hirel B, Becker T. Leaf-specific overexpression of plastidic glutamine synthetase stimulates the growth of transgenic tobacco seedlings. Planta. 2000;210:252-60.

253. Deprost D, Yao L, Sormani R, Moreau M, Leterreux G, et al. The Arabidopsis TOR kinase links plant growth, yield, stress resistance and mRNA translation. EMBO Rep. 2007:8:864-70.

254. Castaings L, Camargo A, Pocholle D, Gaudon V, Texier Y, Boutet-Mercey S, Taconnat L, Renou J-P, Daniel-Vedele F, Fernandez E, Meyer C, Krapp A. The nodule inception-like protein 7 modulates nitrate sensing and metabolism in Arabidopsis. Plant J. 2009;57:426-35.

255. Pathak RR, Ahmad A, Lochab S, Raghuram N. Molecular physiology of plant nitrogen use efficiency and biotechnological options for its enhancement. Curr Sci. 2009;94:1394-403.

256. Lea US, Leydecker MT, Quillere I, Meyer C, Lillo C. Posttranslational regulation of nitrate reductase strongly affects the levels of free amino acids and nitrate, whereas transcriptional regulation has only minor influence. Plant Physiolology. 2006;140:1085-94.

257. Lam HM, Hsieh MH, Coruzzi G. Reciprocal regulation of distinct asparagine synthetase genes by light and metabolites in Arabidopsis thaliana. Plant J. 1998;16:345-53.

258. Harrison J, Brugiere N, Phillipson B, Ferrario-Mery S, Becker T, Limami A, Hirel B. Manipulating the pathway of ammonia assimilation through genetic engineering and breeding: consequences on plant physiology and plant development. Plant Soil. 2000;221:81-93.
259. LopesCardoso Ml, Carvalho H, Lima L, Melo P, Cullimore J. Nodule specific modulation of glutamine synthetase in transgenic Medicago truncatula. Plant Physiol. 2003;133:243-52.

260. Harrison J, Pou de Crescenzo MA, Sene O, Hirel B. Does lowering glutamine synthetase activity in nodules modify nitrogen metabolism and growth of Lotus japonicus? Plant Physiol. 2003;133:253-62.

261. Wong HK, Chan HK, Coruzzi GM, Lam HM. Correlation of ASN2 gene expression with ammonium metabolism in Arabidopsis. Plant Physiol. 2004:134:332-8.

262. Hirel B, Le Gouis J, Ney B, Gallais A. The challenge of improving nitrogen use efficiency in crop plants: towards a more central role for genetic variability and quantitative genetics within integrated approaches. J Exp Bot. 2007;58:2369-87.

263. Radtkey R, Feng L, Muralhidar M, Duhon M, Canter D, DiPierro D, Fallon S, Tu E, McElfresh K, Nerenberg M, Sosnowski R. Rapid, high fidelity analysis of simple sequence repeats on an electronically active DNA microchip. Nucleic Acids Res. 2000;28:E17.

264. Wang Z, Gerstein M, Snyder M. RNA-Seq: a revolutionary tool for transcriptomics. Nat Rev Genet. 2009;10:57-63.

265. Rawal HC, Kumar S, Mithra SVA, Solanke AU. High quality unigenes and microsatellite markers from tissue specific transcriptome and development of a database in Clusterbean (Cyamopsis tetragonoloba, L. Taub). Genes. 2017:8:313.

266. Lian X, Wang S, Zhang J, Feng Q, Zhang L, Fan D, Li X, Yuan D, Han B, Zhang Q. Expression profiles of 10,422 genes at early stage of low nitrogen stress in rice assayed using a cDNA microarray. Plant Mol Biol. 2006;60:617-31.

267. Yang SY, Hao DL, Song ZZ, Yang GZ, Wang L, Su YH. RNA-Seq analysis of differentially expressed genes in rice under varied nitrogen supplies. Gene. 2015;555:305-17.

268. Gelli M, Duo Y, Konda AR, Zhang C, Holding D, Dweikat I. Identification of differentially expressed genes between sorghum genotypes with contrasting nitrogen stress tolerance by genome-wide transcriptional profiling. BMC Genomics. 2014;15:179.

269. Hao QN, Zhou XA, Ai HS, Wang C, Zhou R, Chen SL. Identification of genes associated with nitrogen-use efficiency by genome-wide transcriptional analysis of two soybean genotypes. BMC Genomics. 2011:12:525.

270. Li W, Xiang F, Zhong M, Zhou L, Liu H, Li S, Wang X. Transcriptome and metabolite analysis identifies nitrogen utilization genes in tea plant (Camellia sinensis). Sci Rep. 2017;7:1693.

271. Cho YI, Jiang WZ, Chin JH, Piao ZZ, Cho YG, McCouch SR, Koh HJ. Identification of QTLs associated with physiological nitrogen use efficiency in rice. Mol Cell. 2007;23:72-9.

272. Wei D, Cui KH, Ye GY, Pan JF, Xiang J, Huang JL, Nie L. QTL mapping for nitrogen-use efficiency and nitrogen-deficiency tolerance traits in rice. Plant Soil. 2012;359:281-95.

273. Zhou Y, Tao Y, Tang D, Wang J, Zhong J, Wang Y, Liang G. Identification of QTLS associated with nitrogen uptake and nitrogen use efficiency using high throughput genotyped CSSLs in rice (Oryza sativa L.). Front Plant Sci. 2017:8:1166.

274. Pandit A, Rai V, Bal S, Sinha S, Kumar V, Chauhan M, Gautam RK, Singh R, Sharma PC, Singh AK, et al. Combining QTL mapping and transcriptome profiling of bulked RILs for identification of functional polymorphism for salt tolerance genes in rice (Oryza sativa L.). Mol Genet Genomics. 2013;284:121-36.

275. Curci PL, Bergès H, Marande W, Maccaferri M, Tuberosa R, Sonnante G. Asparagine synthetase genes (AsnS1, and AsnS2) in durum wheat: structural analysis and expression under nitrogen stress. Euphytica. 2018:214:36.

276. Wan Y, King R, Mitchell RAC, Hassani-Pak K, Hawkesford MJ. Spatiotemporal expression patterns of wheat amino acid transporters reveal their putative roles in nitrogen transport and responses to abiotic stress. Sci Rep. 2017;7:5461-74.

277. Dai ZW, Plessis A, Vincent J, Duchateau N, Besson A, Dardevet M, Prodhomme D, Gibon Y, Hilbert G, Pailloux M, et al. Transcriptional and metabolic alternations rebalance wheat grain storage protein accumulation under variable nitrogen and sulfur supply. Plant J. 2015;83:326-43. 
278. Kirkman MA, Miflin BJ. The nitrate content and amino acid composition of the xylem fluid of spring wheat throughout the growing season. J Sci Food Agric. 1979;30:653-60.

279. Todd J, Screen S, Crowley J. Identification and characterization of four distinct asparagine synthetase (AsnS) genes in maize (Zea mays L.). Plant Sci. 2008;175:799-808.
280. Curci PL, Cigliano RA, Zuluaga DL, Janni M, Sanseverino W, Sonnante G. Transcriptomic response of durum wheat to nitrogen starvation. Sci Rep. 2017;7:1176-90.

\section{Publisher's Note}

Springer Nature remains neutral with regard to jurisdictional claims in published maps and institutional affiliations. 